\title{
GABRIEL MIRÓ Y EL 27. LECTURAS E INFLUENCIAS
}

GUILlERMO LAÍN CORONA

Universidad de Málaga / University College London

\section{RESUMEN}

Es objeto de este artículo mostrar que la tradicional - y desacertada - interpretación lírica de Gabriel Miró parte, en gran medida, de manos de los poetas del 27, con quienes aquél mantuvo muy cercanos contactos personales. Analizaremos las lecturas que éstos hicieron de Miró, y el modo en que condicionaron y repercutieron en la crítica mironiana posterior (consolidando el tópico del Miró lírico). Asimismo, ello permitirá estudiar en qué grado influye Miró en estos poetas, de modo que se le considere como uno de los guías de la generación, junto con los otros tradicionalmente citados.

Palabras clave: Gabriel Miró, generación del 27, amistad, lecturas, crítica literaria, influencias, lirismo.

\section{GABRIEL MIRÓ AND THE GENERATION OF 1927. READINGS AND INFLUENCES}

\begin{abstract}
It is the aim of this article to show that the traditional (and not too accurate) lyrical interpretation of Gabriel Miró comes mainly from the poets of 1927, with whom he had very close personal links. I will analyse the different ways in which these poets read Miró, and to which extent these readings determined and had a great impact on the following Mironian critics (which strengthened the topic of Miró's lyricism). This will help to study how much Miró himself influenced these poets, so he can be considered, among others traditionally mentioned, as one of the guides of this generation.
\end{abstract}

Key words: Gabriel Miró, generation of 1927, friendship, readings, Literary criticism, influences, lyricism.

Gabriel Miró (1879-1930) ha sido leído fundamentalmente a la luz de marbetes — poeta en prosa, estilista o lírico- que inciden, para bien o para mal — para criticarle o para alabarle_- en las pronunciadas cualidades estéticas de su prosa, olvidando sus destrezas novelísticas. En los últimos años ya se han pronunciado un buen número de voces reclamando al 
Miró novelista ${ }^{1}$, pero todavía la lectura que se impone en los manuales es la del lírico. Gonzalo Navajas, por ejemplo, ha señalado no hace mucho que, a comienzos del siglo XX, Azorín, entre otros autores, estuvo más preocupado por «a mastery of language», siendo que la elegancia «often became the predominant, or even the sole reason for writing». Por su parte, Gabriel Miró «expanded and developed this tendency towards contemplation and refinement that turned texts into exquisite objets d'arts in accordance with an essentialist aesthetic far removed from the immediate circunstancia of the day» ${ }^{2}$.

Ian R. Macdonald ha explicado los orígenes de esta interpretación en el contexto socio-literario de los años en vida del propio Miró3. Hace notar este crítico que ya entonces se leía a Miró como «a great stylist, a great craftsman of the Castilian language, or even a poet who, rather oddly, chose to write in extended prose forms» ${ }^{4}$. Hubo quienes admiraron esta categoría de estilista, pero la mayoría de críticos la denostó, y al propio Miró no le gustaba. Y es que estilista parecía referirse ante todo a alguien que se limitaba a escribir bien, incluso muy bien, pero que no tenía nada que decir. En el caso de Miró, la etiqueta presentaba un escritor de bellas palabras, pero no de novela, como resumía José Ortega y Gasset, en una de las más destructivas y desacertadas críticas de Miró. Para Ortega, El obispo leproso (1926) «no queda avecinada entre las buenas novelas», y

\footnotetext{
${ }^{1}$ Entre los críticos que han estudiado más de cerca la dimensión narrativa de la obra mironiana, pueden destacarse: MÁRQUEZ VILLANUEVA, Francisco. La esfinge mironiana y otros estudios sobre Gabriel Miró. Alicante: Instituto de Cultura Juan Gil-Albert, 1990; MACDONALD, Ian R. (que ya planteaba la necesidad de revalorizar al Miró novelista en su inicial). Gabriel Miró: His Private Library and His Literary Background. London: Tamesis, 1975; Macdonald ha continuado destacando la dimensión narrativa de Miró hasta muy recientemente, por ejemplo, en «Figuras de la Pasión del Señor, novela». En: LOZANO MARCO, Miguel Ángel; Biblioteca Gabriel Miró (coords.). Actas del II Simposio Internacional "Gabriel Miró». Alicante: Caja de Ahorros del Mediterráneo, 2004, pp. 81-95; RALLO, Asunción. (en dos lucidísimos artículos). «Fábula e ironía: Las cerezas del cementerio de Gabriel Miró». Epos. Revista de Filología, 1986, 2, pp. 253-279, y «De la organización poemática al discurso narrativo en Gabriel Miró: Los pies y los zapatos de Enriqueta». Analecta Malacitana, 1986, 9.1, pp. 141-151; ONTAÑÓN DE LOPE, Paciencia. Estudios sobre Gabriel Miró. México: Universidad Nacional Autónoma de México, 1979; Miguel Ángel Lozano Marco y Edmund L. King (críticos con una larga trayectoria de estudios mironianos, ambos han estudiado la dimensión narrativa de la obra de Miró, como en sendos ensayos publicados en RUIZ SILVA, Carlos et al. La novelística de Gabriel Miró. Nuevas perspectivas. Alicante: Instituto de Cultura Juan Gil-Albert-Diputación, 1993).

${ }^{2}$ NAVAJAS, Gonzalo. «The Spanish Novel in the Twentieth Century». En ALTISENT, Marta E. (ed.). A Companion to the Twentieth-Century Spanish Novel. London, Tamesis, 2008, pp. 17-29 (p. 21). El comentario sorprende no sólo porque lo aplica incluso a dos obras de Miró tan indiscutiblemente novelísticas —Nuestro Padre San Daniel y El obispo leproso-, sino por estar incluido en un libro editado por una mironista como Altisent.

${ }^{3}$ Véase el primer capítulo, «Miró and his Critics», de su ya citado Gabriel Miró, pp. 5-37.

${ }^{4}$ Ibidem, p. 8.
} 
todo por no ser Miró más que un «pulcro» prosista. Ortega alaba su estilo casi porque no le queda otra cosa que alabar, y aun la forma que tiene de hacerlo es tan tortuosa como sarcástica:

No creo que haya actualmente escritor más pulcro y solícito. Cada frase está hecha a tórculo. Cada palabra, ensamblada con las vecinas, y luego, pulida la coyuntura. Y no hay línea que suba ni que baje en la página: todo el libro conserva la misma ardiente tensión, idéntico cuidado, pulso y pulimento. Tanto, que acaso este son persistente de prima hiperestesiada colabora a la fatiga, no dejando respiro: la perfección de la prosa es en Miró impecable e implacable 5 .

Esta noción negativa de estilista, aplicada a Miró, se explica fundamentalmente en el marco estético de la época. Como ha señalado Carlos A. Longhurst, a comienzos del siglo XX hubo un encendido debate sobre lengua y estilo en España: «In the case of Spanish writers one can reasonably posit that the common interest in language starts off as an interest in style and expression, instigated by what they saw as the clichéd rhetoric of Restauración prose». Y añade que, fruto de esta aversión al exceso retórico anterior, los escritores de esa época compartieron «a distrust, or at the very least a questioning, of the power of language to communicate worthwhile truths» ${ }^{6}$. La consecuencia lógica de esta actitud de rechazo a la retórica pasada y de la falta de confianza en la capacidad de comunicación del lenguaje es la aversión por el estilo. Así, como señala Longhurst, el caso de Pío Baroja: «Baroja's innate scepticism about all systems made him deeply suspicious of language as an expressive tool [...] hence his movement away from the modernista style of his earlier work towards a much sober, even laconic, form of expression» ${ }^{7}$. Miró, según Longhurst, compartiría algo con estos autores alboseculares: tampoco cree que el lenguaje pueda atrapar la verdad del mundo objetivamente. Pero en Miró, a diferencia de aquellos, «la palabra es la misma idea hecha carne» ${ }^{8}$. Miró, pues, a diferencia de sus coetáneos, tiene confianza en la capacidad expresiva del lenguaje, pero una confianza de índole estética y subjetiva. El mundo, no como es objetivamente, sino como lo siente el que lo contempla, sólo lo es del todo cuando recibe «la fuerza lírica de la palabra, su palabra plena y exacta», según Miró en El humo dormido (1919) . Como

${ }^{5}$ ORTEGA Y GASSET, José. «El obispo leproso. Novela, por Gabriel Miró». En Obras completas III (1917-1928). Madrid: Revista de Occidente, 1966, pp. 544-550 (pp. 545-546).

${ }^{6}$ LONGHURST, Carlos A. «Telling Words: Unamuno and the Language of Fiction». Bulletin of Spanish Studies, 2006, 83.1, pp. 125-147 (p. 126).

7 Ibidem, p. 128.

${ }^{8}$ MIRÓ, Gabriel. «Nombres y recuerdos». En Glosas de Sigüenza. Buenos AiresMéxico: Espasa-Calpe Argentina, 1952, pp. 114-128 (p. 118).

${ }^{9}$ MIRÓ, Gabriel. Obras completas. Madrid: Biblioteca Nueva, 1969, p. 692. En adelante, todas las referencias a las obras de Miró se harán por esta edición, con la abreviatura $O C$ más n. ${ }^{\circ}$ de p. entre paréntesis, excepto aquellos textos suyos no recogidos aquí, que se indicarán pertinentemente. 
explica Longhurst: «The exactitude of which Miró speaks is an aesthetic one, referred to emotions, not objects, even if those emotions are reached via the contemplation of objects. [...] Words do not substitute for reality but move it to a higher plane of perception». Miró, por eso, cuida tanto su lenguaje, y de ahí sus diferencias con otros escritores de la época: «Yet unlike Baroja and Azorín, and despite his admiration for the latter, he did not strive to streamline expression, but rather to renovate it through lexical expansion ${ }^{10}$.

Pese al común punto de partida en la concepción del lenguaje (el rechazo de la idea de que pueda éste atrapar el mundo objetivo), la actitud de, digamos, Baroja y la de Miró difieren tremendamente. Por su desconfianza en la capacidad comunicativa (contenido) del lenguaje (forma), Baroja termina por entender forma y contenido como entes completamente desligables, de modo que, para él, el cuidado estético de lo primero no puede ser sino mero estilismo, «barroquismo» o «carácter palabrero de la retórica española» ${ }^{11}$. Miró, empero, abrazó un nuevo tipo de confianza en el lenguaje, esto es, como medio de expresión subjetivo que implicaba la depuración estética del mismo. Quienes tildaron negativamente a Miró de estilista lo hacían precisamente por no comprender esto. O dicho con MacDonald: la interpretación de Miró como estilista se basó en la «extreme separation of form and content; it depends on the critic believing that style is a matter of the plaster embellishments on a brick structure, of externally applied ornaments on a text that would still mean the same without its «style», though it might be less of a pleasure to the reader» ${ }^{12}$.

Si la interpretación de Miró como estilista (con su tremenda carga negativa) se basa en la separación radical entre forma y contenido, esta división, a su vez, es fruto, según Macdonald, de unos principios estéticos pasados de moda: la supervivencia de la estética del siglo XVIII durante el siglo XIX y principios del XX en España ${ }^{13}$. La lectura de Miró como estilista, además de negativa y desacertada, era, por tanto, anacrónica, y no tenía en consideración la modernidad que éste y otros escritores estaban introduciendo en España, en paralelo a los avances literarios europeos. La hipótesis casa muy bien con las ideas de Longhurst antes expuestas, pues, de todos los novelistas jóvenes de comienzos del siglo XX cuyo desengaño sobre el lenguaje analiza este crítico, Baroja es el que maneja unos principios estéticos más antiguos ${ }^{14}$, y su postura, como vimos, se presta muy bien

${ }^{10}$ LONGHURST. «Telling», p. 130.

${ }^{11}$ Cfr. LONGHURST. «Telling», p. 128.

${ }^{12}$ MACDONALD, Gabriel Miró, p. 10.

${ }^{13}$ Ibidem, pp. 10-11.

14 «Baroja and [Vicente] Blasco [Ibáñez] belong to an intermediate stage of development and stand as near-perfect example of halfway house between Naturalism and Modernism». Véase LONGHURST, Carlos A. «Ruptures and Continuities: From Realism to Modernism 
a entender a Miró como estilista ${ }^{15}$. Macdonald, por su parte, intenta explicar lo erróneo de la crítica de Ortega sobre El obispo leproso, argumentando que incluso su estética de La deshumanización del arte (1925) no es sino una manera sofisticada de defender la misma separación arcaica entre forma y contenido ${ }^{16}$.

Sólo quienes entendieron la noción de estilo con parámetros más modernos, que implican la reconciliación de la expresión y lo expresado, pudieron leer a Miró desde una óptica positiva. Como muestra Macdonald, fueron los críticos de Madrid los que más le denostaron porque fueron también los que malinterpretaron su obra con nociones estéticas anticuadas. Mientras que en Barcelona, con una mentalidad estéticamente mucho más moderna, se le apreció y comprendió mejor. En efecto, para gente como Joan Maragall, Miró también es un estilista, pero en un sentido más positivo, porque, para el catalán, y en palabras de Macdonald: «this is not style for style's sake» ${ }^{17}$. Es muy interesante la comparación que lleva a cabo este crítico al respecto. Supone que Miró fue denostado en su tiempo en los mismos términos que Góngora: por la consideración del estilo como un ornamento gratuito. De modo que, en referencia a los escritores del 98, señala:

[...] with the exception of Azorín, they all disliked Góngora as much as their nineteenth-century predecessors did. Maeztu, Baroja, Machado, Unamuno, and Valle-Inclán all expressed ignorance, indifference, or hostility. The parallel between these attitudes and the same writers' view of Miró is remarkable. Only Unamuno diverges sharply for as we have seen he was an enthusiastic admirer of Miró ${ }^{18}$.

Como el de Miró, el desprecio sistemático de Góngora se basaba en el rechazo a todos los, por así decir, excesos barrocos. Pero estos excesos sólo podían serlo para quienes todavía no eran capaces de comprender las modernas implicaciones estéticas. Tuvieron que ser los miembros de la nueva generación de poetas los que corrigieran este rechazo. Los poetas del 27 rescataron y comprendieron a Góngora, y con él como estandarte entronizaron una estética más moderna, de culto al lenguaje, pero no puramente ornamental. Y ello en paralelo a la lectura que de Miró hicieron.

Suele olvidarse que el tricentenario gongorino se llevó a cabo, en parte, a instancias de Miró. Gerardo Diego admite que le debe a éste en gran

and the Avant-Garde». En: LOUGH. Francis (ed.). Hacia la novela nueva. Essays on the Spanish Avant-Garde Novel. Oxford/Bern/Berlin/Bruxelles/Frankfurt am Main/New York/ Wein: Lang, 2000, pp. 19-41 (p. 22).

${ }^{15}$ La opinión de Baroja sobre Miró es, de hecho, negativa: «A mí me parece que Miró no es un hombre cuya obra tenga una raíz fuerte en la realidad». Véase ROMANO, Julio. «Pío Baroja nos habla del escritor Hermann Hesse». Madrid, 20 de noviembre de 1946, p. 3.

16 MACDONALD. Gabriel Miró, pp. 29-30.

17 Ibidem, p. 15.

18 Ibidem, p. 22. 
medida su interés por Góngora ${ }^{19}$, hasta el punto de que le mandó un ejemplar dedicado de su Antología poética en honor de Góngora ${ }^{20}$. Dámaso Alonso recuerda el papel de Miró a través de los Concursos Nacionales ${ }^{21}$; agradecido, también él le mandó, dedicados, sendos ejemplares de Góngora: Soledades y Temas gongorinos. Y es que «in 1927 the nacional competitions of the Ministry of Public Education were devoted to Góngora, at the instigations of Miró, secretary of the competitions» ${ }^{22}$; como miembro del jurado de la lid, Miró favoreció la concesión del Premio Nacional de Literatura a dos autores del 27: Alberti y Diego ${ }^{23}$. Más aún, Miró «was put in charge of organizing the celebrations in Seville of the tricentennial of the death of the baroque poet Luis de Góngora» ${ }^{24}$. Seguramente fue por ello por lo que le mandaron una postal desde Sevilla, firmada por Guillén, Alberti, Lorca, Alonso, José Bergamín, Diego, Fernando Villalón y José Bello: «Todos participamos en la admiración y cariño a Sigüenza» ${ }^{25}$.

Parece claro que el renacer de Góngora le debe mucho a Miró. A su vez, la nueva y positiva interpretación del poeta barroco que llevan a cabo los poetas del 27 corre paralela a su nueva y positiva manera de leer a Miró. Defienden a ambos por su lenguaje; y entienden éste como un modo de expresión, no como un mero ornamento. Es interesante que Jorge Guillén los estudie a ambos en sendos ensayos incluidos en un libro de título significativo: Lenguaje y poesía $(1962)^{26}$. Guillén muestra aquí no sólo su defensa de Miró, sino la moderna comprensión de su obra. Porque Guillén explica a Miró con unas palabras que prácticamente parafrasean la noción mironiana de la palabra como idea hecha carne: «La expresión constituye, pues, una conquista espiritual, que en último término será creación estética. Vida con espíritu más forma dentro de una sola identidad indivisible:

${ }^{19}$ DIEGO, Gerardo; COSSÍO, José María. Epistolario. Nuevas claves de la Generación del 27. Gómez de Tudesca, R. (ed.). Alcalá de Henares: Universidad-FCE, 1996, p. 113.

${ }^{20}$ Éste y los demás ejemplares dedicados que cito a continuación se conservan en la biblioteca de Miró, y pueden verse en el catálogo incluido por Macdonald, Gabriel Miró, pp. 205-227.

${ }^{21}$ ALONSO, Dámaso. «Gabriel Miró en mi recuerdo». En Poetas españoles contemporáneos. Madrid: Gredos, 1969, pp. 149-154 (pp. 152-153).

22 MACDONALD. Gabriel Miró, p. 21.

${ }^{23}$ ALBERTI, Rafael. La arboleda perdida. Barcelona: Seix Barral, 1981, I, ha explicado la participación de Miró como miembro del jurado (p. 175) y las dificultades que hubo para conceder ese año dos premios de poesía (pp. 198-200).

${ }^{24}$ ALTISENT, Marta. «Gabriel Miró (28 July 1879-27 May 1930)». En: MARTÍNEZCARRAZO, Carmen; ALTISENT, Marta (eds.). Dictionary of Literary Biography. Volume 322: Twentieth-Century Spanish Fiction Writer. Farmington Hills: MI, Thomson Gale, 2006, pp. 221-230 (p. 228).

${ }^{25}$ GUILLÉN, Jorge. En torno a Gabriel Miró. Breve epistolario. Madrid: Arte y Bibliofilia, 1970, pp. 136-137.

${ }^{26}$ Publicado previamente en inglés en 1961. 
¿no será eso la poesía?» ${ }^{27}$. Forma (palabra en Miró, expresión en Guillén) inseparable del contenido (idea hecha carne o vida más espíritu).

Esta mejor comprensión de Miró y Góngora por parte del 27 se enmarca, de nuevo, en el debate estético de la época. Porque, como señala Longhurst, frente a la reacción noventayochista contra el retoricismo de la Restauración:

The novelists of the historical Avant-Garde went much further. They understood one crucial point; that in a universe built of words expression is everything. You cannot innovate simply by changing the subject of a novel; you have to change the expression. This they had in common with the «Generación poética del 27», whose members had the effrontery, but also the enormous vision, to resurrect the Golden Age poet condemned for generations for his linguistic creativity, Luis de Góngora ${ }^{28}$.

La actitud del 27 es más positiva y comprensiva con Miró, y pone en entredicho el marbete de estilista. Sin embargo, constituye todavía una visión limitada. Porque, como Macdonald ha señalado, los poetas del 27 se centraron sólo en los aspectos de Miró que más les interesaban, los poéticos:

Their preoccupations meant that the «estilista» argument was superseded, but Miró the novelist, the organiser of large-scale works, remained, by and large, unrecognised. For these young admirers the question of overall structure was simply not interesting; their attention was centred in Miró the linguistic creator ${ }^{29}$.

Con el 27, pues, se pasó del marbete de estilista (negativo por su asociación a la estética desfasada que separaba forma de contenido, y entendía el estilo como mero ornamento) al de lírico, que, aunque más positivo y comprensivo con la estética de Miró, olvidaba igualmente al novelista. De esta nueva valoración da cuenta un breve análisis de las opiniones de los poetas del 27 sobre Miró.

Exaltaron de éste sólo los aspectos que consideraron plenamente poéticos, especialmente la palabra y el estilo en que ésta se expresa. De sus obras, se refieren menos a sus novelas propiamente dichas que a libros como los de Sigüenza o El humo dormido, donde ven que se proyecta mejor el Miró poeta. Guillén recuerda cómo «cada día leemos nuestro evangelio, el Evangelio según San Gabriel, el del Humo dormido» ${ }^{30}$. En el estudio de Diego sobre Miró, uno de los aspectos más atentamente estudiados es «La

${ }^{27}$ GUILLÉN, Jorge. «Lenguaje suficiente: Gabriel Miró». En Lenguaje y poesía. Madrid: Alianza, 1972, pp. 143-179 (p. 147). La comparación es pertinente, desde un punto de vista cronológico, ya que, para cuando Guillén escribe por primera vez este ensayo (1961), el escrito en que Miró se refiere a la palabra como idea hecha había aparecido, primero, en 1912 y, luego, recopilado póstumamente en Glosas de Sigüenza (1952).

${ }_{28}$ LONGHURST. «Ruptures», pp. 38-39.

${ }^{29}$ MACDONALD. Gabriel Miró, pp. 25-26.

${ }^{30}$ GUILLÉN. En torno, p. 125. 
palabra ${ }^{31}$; en la breve antología que incluye a continuación de este artículo, cita Años y leguas (1928) en cuatro ocasiones, El humo dormido en dos y El ángel, el molino, el caracol del faro (1921) en una, y sólo dos veces toma sus ejemplos de novelas, uno de La novela de mi amigo (1908) y otro de Nuestro Padre San Daniel (1921). El mismo Diego, al prologar El obispo leproso, dedica mucho más tiempo a tratar de Sigüenza que de la novela que le incumbe, e insiste en suprimir lo narrativo: «su arte es estampa» ${ }^{32}$. Alonso, resaltando al Miró que era, «ante todo, un gran poeta en prosa», un «escritor de «estampas»», recuerda que «cuatro o cinco muchachos fervorosos leíamos y comentábamos en voz alta trozos del $\mathrm{Li}$ bro de Sigüenza [1917] o de El humo dormido» ${ }^{33}$. Cuando estos poetas se refieren a las novelas, aun reconociendo su faceta narrativo-novelística, lo hacen subordinándola a lo lírico. Guillén, por ejemplo, reconoce la acción narrativa: «este mundo - lírico, novelesco- no es ni podría ser un mundo inmóvil» ${ }^{34}$; sin embargo, ese mundo es antes lírico que novelesco. Salinas «provides an excellent example of this lack of interest in novelistic structure; in a lecture given in 1931, he presents Miró as having rescued prose from its servitude to narrative» ${ }^{35}$.

Esta imagen lírica de Miró en manos del 27 puede estar en la base de mayor parte de la crítica mironiana posterior. Véanse algunos ejemplos concretos. Francisco Javier Díez de Revenga considera a los poetas del 27 los mejores críticos de Miró por su estudio de lo lírico ${ }^{36}$, y él mismo fomenta la consideración lírica tradicional en su estudio. Por otra parte, una rápida ojeada a la bibliografía mironiana desvelará el interés mayoritario de la crítica por aspectos lírico-estilísticos. Rosario Martínez Galán ofrece una interesante gráfica en la que pueden percibirse tres grandes momentos en la crítica mironiana ${ }^{37}$ :

${ }^{31}$ DIEGO, Gerardo. «Gabriel Miró». Cuadernos de Literatura Contemporánea, 1942, 5-6, pp. 200-208.

${ }^{32}$ DIEGO, Gerardo. «Prólogo». En Obras completas. Edición Conmemorativa emprendida por los «Amigos de Gabriel Miró». Barcelona: Altés, 1932-1949, XI, pp. vii-xvi (pp. viii-ix).

33 ALONSO. «Gabriel Miró», p. 149.

${ }^{34}$ GUILLÉN. Lenguaje, p. 165.

${ }^{35}$ MACDONALD. Gabriel Miró, p. 28.

${ }^{36}$ DÍEZ DE REVENGA, Francisco Javier. «Gabriel Miró y los poetas del 27». En: ROMÁN DEL CERRO, Juan Luis (ed.). Homenaje a Gabriel Miró. Estudios de crítica literaria. En el centenario de su nacimiento, 1879-1979. Alicante: Caja de Ahorros Provincial, 1979, pp. 243-263 (p. 245).

${ }^{37}$ MARTÍNEZ GALÁN, Rosario. Arte y técnica en la narrativa de Gabriel Miró. Cádiz: Servicio de Publicaciones de la Universidad de Cádiz, 1990, p. 20. 


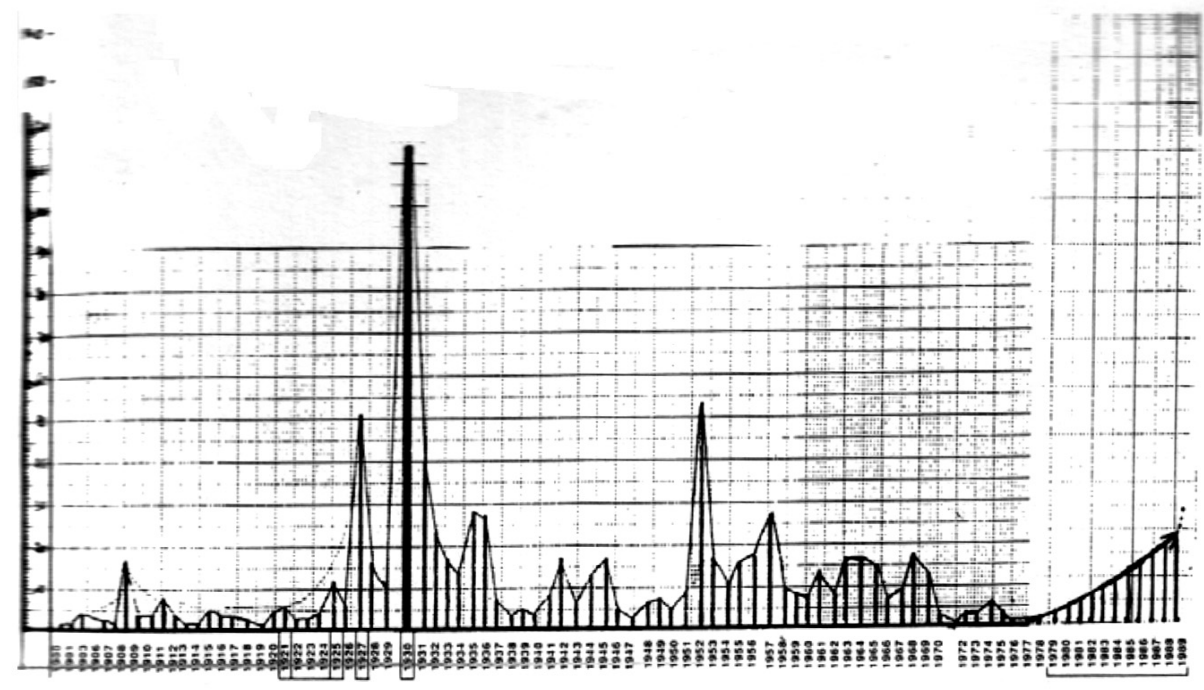

Gráfica de la crítica mironiana.

Uno, que atribuye al interés que se desprende del artículo de Ortega sobre El obispo leproso, se da, curiosamente, en 1927; otro data de 1930 (año de la muerte de Miró), y un último tiene lugar en 1952. Es muy probable que el pico de 1927, a la sombra de aquella generación y de su interés por la dimensión estética de la obra mironiana, sea responsable de los demás picos de interés crítico por Miró, y de que ese interés se centre en lo estilístico. Por ejemplo, el estudio de Mariano Baquero Goyanes, La prosa neomodernista de Gabriel Miró, que repasa las cuestiones de estilo de la prosa mironiana, se publicó por primera vez justo en 1952.

Jorge Guillén alaba en Miró el uso de los genitivos en cascada ${ }^{38}$, y éste es uno de los aspectos más estudiados desde entonces en torno a Miró, como hace Carlos Sánchez Gimeno ${ }^{39}$. Oswaldo Maya Cortes analiza la prosa de Miró para la descripción de paisajes a partir de la estilística de Dámaso Alonso $^{40}$. Y ciertos estudiosos se han referido a Miró como prosista puro, en claro paralelismo con la poesía pura de Guillén ${ }^{41}$ : el ya citado Sánchez

${ }^{38}$ GUILLÉN. Lenguaje, p. 151.

39 SÁNCHEZ GIMENO, Carlos. Gabriel Miró y su obra. Valencia: Castalia, 1960, pp. 97-118.

${ }^{40}$ MAYA CORTES, Oswaldo. «Prosa paisajística mironiana a través de la estilística de Dámaso Alonso». Cuadernos Hispanoamericanos. 1973, 280-282, pp. 399-424.

${ }^{41}$ Guillén se hacía adalid de esta forma de entender la poesía en su carta a Fernando Vela. Puede consultarse en GONZÁLEZ MUELA, Joaquín y ROZAS, Juan Manuel (eds.). La generación poética de 1927: estudio, antología y documentación. Madrid: Alcalá, 1966, pp. $239-240$. 
Gimeno afirma que en la prosa de Miró «predomina la poesía pura» y que «es prosa por la prosa ${ }^{42}$; Miguel Martínez-Mena, a partir de varios testimonios, califica a Miró como «Puro escritor» ${ }^{43}$, y Ricardo Landeira explica que en sus últimas obras Miró depura «su arte narrativo hasta convertirlo en prosa pura» ${ }^{44}$.

Por su parte, en su magistral libro El ser y la palabra en Gabriel Miró, Roberta L. Johnson perpetúa el tópico de la palabra mironiana, tan estudiada por el 27; concretamente en la dimensión más filosófica, deudora de Guillén. Y es que la interpretación guilleniana del lenguaje de Miró tiene un trasfondo evidentemente filosófico. Para Guillén, lo fundamental del lenguaje de Miró es su exactitud, la adecuación a lo nombrado, la posibilidad de que lo inefable sólo lo sea, paradójicamente, una vez que ha sido sublimado al decirlo (expresarlo y pronunciarlo). La palabra es, en suma, para Miró y en opinión de Guillén, un acto de alegría que resulta de pronunciar el mundo, llegando así a un mejor conocimiento del mismo. En cierto modo, en Guillén ya subyace el título del libro de Johnson: que la palabra expresa con precisión el ser. Johnson profundiza en esta interpretación de Miró, y termina por sustituir el marbete de lírico por el de filósofo, ya que, en su «monografía vamos en busca del Miró filosófico» ${ }^{45}$.

Otro tópico sustentado por el 27 y repetido posteriormente ha sido el del paisaje y la asociada sensualidad de la prosa, por el empleo recurrente de Miró de todos los sentidos, especialmente en la contemplación del mismo. Guillén, a la consideración de que «No hay paisajista más fuerte que Miró en la literatura española», añade: «sin el hombre [el paisaje] no existe. Para nosotros sólo existirá humanizado» ${ }^{46}$. La humanización del paisaje es una de las grandes aportaciones de Salinas a la crítica mironiana. El paisaje opuesto tanto a la concepción clásica (que lo describe objetivamente) como a la romántica (paisaje subjetivo, humanizado porque refleja el alma del poeta). Según Salinas, el paisaje en Miró tiene «un alma propia, un querer ser así y no de otro modo, una individualidad latente y prisionera. Y desde el momento que algo tiene alma, es humano» ${ }^{47}$. Paisaje, además, trascendido. Salinas explica cómo Miró, en el debate tradicional entre lo terrenal y lo celestial, se decanta por lo terrenal, esto es, por la materiali-

${ }^{42}$ SÁNCHEZ GIMENO, Carlos. Gabriel Miró, pp. 70 y 99.

${ }^{43}$ MARTÍNEZ-MENA, Miguel. Gabriel Miró: Junto a los ángeles. Alicante: Caja de Ahorros Provincial, 1981, p. 61.

${ }^{44}$ LANDEIRA, Ricardo. Trilogía de Sigüenza. Chapel Hill, NC: Estudios de Hispanofilia, 1972, p. 19.

${ }^{45}$ JOHNSON, Roberta L. El ser y la palabra en Gabriel Miró. Madrid: Fundamentos, 1984 , p. 9.

${ }^{46}$ GUILLÉN. Lenguaje, p. 153.

${ }^{47}$ SALINAS, Pedro. «Prólogo» a Gabriel Miró. Obras completas. Edición conmemorativa, VII, pp. ix-xxi (p. xv). 
dad de la existencia. De ahí la importancia de los sentidos en Miró, en especial, según Salinas, el tacto ${ }^{48}$. Para Guillén, son todos los sentidos, si bien «quizá el olfato intervenga aún más finamente». Y explica: «Se dirigía su empeño hacia la captación de una realidad revelada a través de los sentidos y los sentimientos», porque para Miró «sensualidad es espíritu» ${ }^{49}$.

Por su parte, Margarita de Mayo, prácticamente a la par de los comentarios anteriores, señalaba: «Gabriel Miró [...] mira y siente la naturaleza como si en ella se ofreciera lo humano. Humaniza las piedras, las plantas, las estrellas. [...] Incorpora al paisaje una humanidad más atrayente y penetrante que la que otorga a sus criaturas ${ }^{50}$. Y Eugenio G. de Nora, haciéndose eco de la interpretación del paisaje mironiano entre la tierra (sentidos, sensualidad) y el cielo (trascendencia, espíritu), destaca «esa especie de «misticismo materialista» que impregna la obra mironiana» ${ }^{51}$. Son sólo dos casos de una larga lista que ha insistido en la sensualidad y el paisaje de la obra de Miró.

Como último ejemplo del condionamiento del 27 en la crítica mironiana, nótese el caso de Guillermo Kaul. Este crítico explica en cierto momento la obra de Miró a partir de un estudio sobre Guillén: «Miró, como escribe Casalduero de Guillén, 'desnuda la luz y el agua, en busca siempre de la luz que sea más luz y del agua que sea más agua' ${ }^{52}$.

No sería justo decir que, por tópicos, los aspectos aquí señalados sean falsos. En efecto, hay en Miró una importante dimensión lingüística, paisajística y sensual, de connotaciones líricas. Lo que ha de hacerse notar es que, después de que los poetas del 27 estudiaran estos aspectos con gran maestría, la crítica posterior se ha limitado a repetirlos, a veces, acaso, con aproximaciones más profundas. Tampoco sería de recibo echar en cara a esta generación su determinada manera de leer a Miró. Al fin y al cabo, sus miembros fueron en su mayoría poetas, y se interesaron, consiguientemente, en los aspectos poéticos. Además, antes del 27 ya había habido críticos que habían manejado una imagen parecida de Miró. Claro que entonces, como hemos visto, el juicio mayoritario había sido negativo: Miró como estilista. Y el juicio de la crítica mironiana hasta muy recientemente ha sido, como el del 27, casi siempre positivo: Miró lírico. También hubo lectores anteriores al 27 que alabaron a Miró por sus cualidades líricas,

${ }^{48}$ Ibidem, pp. xvi-xx.

${ }^{49}$ GUILLÉN. Lenguaje, pp. 154, 150 y 155.

${ }^{50}$ MAYO, Margarita de. «Gabriel Miró: Vida y obra». Revista Hispánica Moderna, 1936, 2 , pp. 193-204 (p. 200).

${ }^{51}$ Es significativo, ya desde su título, este trabajo de Eugenio G. de Nora. «La novela sensual de Miró». En La novela española contemporánea. Madrid: Gredos, 1973, I, pp. 431-466 (p. 438).

${ }^{52}$ KAUL, Guillermo. «El estilo de Gabriel Miró». Cuadernos de Literatura, 1948, 4.10, pp. 91-138 (p. 104). 
como los catalanes o Unamuno ${ }^{53}$, pero fueron los menos. Por lo que lo más probable es que la crítica posterior haya basado sus juicios de Miró como lírico más bien en el 27, especialmente porque dos de sus miembros, Salinas y Guillén, fueron, además de poetas famosos, prestigiosos e influyentes profesores de universidad. En cualquier caso, hay una cosa que difícilmente puede negarse. En mitad del debate de Miró como estilista (visión negativa), la defensa positiva de Miró como lírico, en manos del 27, fue en efecto más comprensiva (por entender la relación fundamental entre forma y contenido) y bienintencionada, pero seguía ignorando al novelista, así como muchos de sus contenidos ideológicos, de modo que perpetuaba una lectura en gran medida superficial y poco acertada.

El caso es que los poetas del 27, con los datos que ya se han ofrecido y a partir de otros que se van a dar, es evidente que admiraron a Miró, siquiera desde un punto de vista lírico. Con lo que es plausible considerarle como uno de sus maestros ( $\sin$ menoscabo, por supuesto, de otros ya reconocidos y estudiados, como Juan Ramón Jiménez). Se van a ver algunos aspectos que vienen a confirmar esta posible influencia. He decidido centrarme, para ello, en Guillén, Salinas, Alonso, Diego y Alberti, aquellos con los que Miró mantuvo una relación mucho más estrecha, como ya se ha visto en parte y en lo que se profundizará ${ }^{54}$. Y he añadido también a Lorca, pese a no haber indicios directos ${ }^{55}$, por razones que se verán más adelante.

${ }^{53}$ Unamuno, en efecto, destacó muy encarecidamente el aspecto lírico-poético de la obra de Miró; en referencia a las cualidades estéticas de Figuras de la Pasión, señalaba: «Lástima que todo esto esté en prosa. Debería estar en verso. Aunque la prosa en que está escrito, numerosa y rica, llena de jugo campesino [...], vale por verso» («Miró visto por Unamuno», La Gaceta Literaria, 1 de junio de 1931, p. 5). Claro que Unamuno, finísimo lector, no perdió de vista otras cuestiones subyacentes, como le expresa personalmente a Miró en una carta: «Su Oleza - toda España- me ha levantado del lecho del corazón susurro de amarguras emponzoñadas. ¿Qué bien ha calado usted a los jesuitas! Al rematar la lectura de su libro siento el viejo reino inquisitorial palpitar en las orillas del universo. [...] por debajo de su triste relato de pasiones recoletas, más bien por dentro, he tenido todo el estertor de ese régimen policíaco, que no político - la política es algo muy noble - sino a todo el régimen, el moral, el intelectual, el cultural, hasta religioso. Porque ahí se están pudriendo la religión y la religiosidad bajo las espuelas que tiemblan. Tiemblan del despecho, de envidia, de ruindad» (RUIZ SILVA, Carlos. «Centenario de Gabriel Miró (Epistolario inédito MiróUnamuno)». Ínsula, 1979, 392-393, pp. 9 y 16, p. 16.

${ }^{54}$ Léase también a DÍEZ DE REVENGA, loc. cit., y a ALTISENT, Marta. «Miró, Salinas y Guillén: tres poéticas de la claridad». En: SOTELO VÁZQUEZ, Adolfo; CARBONELL, Marta Cristina (eds.). Homenaje al profesor Antonio Vilanova. Barcelona: Promociones y Publicaciones Universitarias-PPU, II, 1989, pp. 17-40.

${ }^{55}$ A excepción de la postal, ya citada, que le mandaron desde Sevilla varios autores, entre ellos Lorca, y de una carta en la que éste se adhería a quienes defendieron a Miró cuando tan injustamente se le negó el premio Fastenrath. Tomo este último dato de una carta sin fecha del archivo particular de la familia de Gabriel Miró. Cfr. Altisent, «Miró, Salinas y Guillén», p. 21. 
La nómina queda justificada, además, de considerar el triángulo Góngora-Miró-27. Nótese que son estos poetas los más entusiastas de la causa gongorista ${ }^{56}$, hasta el punto de que Alonso escribe: «Nuestro centenario fue idea de Gerardo Diego. Las cartas de invitación a colaborar en él iban firmadas por J. Guillén, P. Salinas, D. Alonso, G. Diego, F. García Lorca y R. Alberti» ${ }^{57}$. Y el propio Miró jugueteó también con temas gongorismos en su literatura ${ }^{58}$.

Claro que el concepto de influencia es demasiado escurridizo. Alonso, sobre la posible influencia de Góngora en la literatura de su tiempo, matiza que se dio «un contacto remoto con el arte de Góngora: en Miró, el ansia de perfección, el cuidado del pormenor estilístico, el conocimiento del valor lógico, óptico y auditivo de las palabras». Y añade que en los poetas de su grupo las influencias «no son fundamentales, sino adjetivas, y no vienen de Góngora, sino van a coincidir con Góngora, para cobrar en su ejemplo augusto nuevo aliento y nuevo impulso. Góngora no influye, reinfluye ${ }^{59}$. Góngora no deja su huella directamente en el 27 , sino a través de filtros. He aquí que podría considerarse a Miró como uno de tales filtros. Por razones parecidas, podría pensarse que en realidad lo que ocurre es que se da entre Miró y el 27 una confluencia estética: haber llegado a planteamientos semejantes, por lazos de relación e intereses comunes como Góngora. Pero ello no impediría considerar a Miró como cierto tipo de guía de la generación. Por otra parte, la noción de influencia aquí conlleva ciertos casos problemáticos. No ha sido posible encontrar vínculos temáticos y estilísticos sólidos en la poesía de Alonso como para entender que en efecto Miró influyó en él de un modo estricto, con lo que en su caso el magisterio de éste no es sino como profunda y reconocida admiración. Inversamente, en el de Lorca, aunque no haya testimonios directos de que conociera y admirara a Miró, no obstante podrán darse algunas notas bastante interesantes. Sólo en algunos casos hay indicios del todo claros. Guillén, por ejemplo, decide incluir en Lenguaje y poesía no sólo a Góngora y a Miró juntamente, sino a éste precisamente en el capítulo anterior al de su generación. Igual hace Alonso en Poetas españoles contemporáneos. Parece un reconocimiento inconsciente de Miró como maestro inmediato de la generación.

${ }^{56}$ MACDONALD. Gabriel Miró, p. 27.

${ }^{57}$ ALONSO, Dámaso. «Góngora y la literatura contemporánea». En Estudios y ensayos gongorinos. Madrid: Gredos, 1955, pp. 532-579 (575-576).

${ }^{58}$ Véase mi artículo «Gongorismo en Las cerezas del cementerio de Gabriel Miró». En: MORÓN ESPINOSA, Antonio César y RUIZ MARTÍNEZ, José Manuel (eds.). En teoría hablamos de literatura. Actas del III Congreso Internacional de Aleph (Granada, 3-7 de abril de 2006). Granada: Asociación Aleph-Departamento de Lingüística General y Teoría de la Literatura de la Universidad de Granada-DAURO, 2007, pp. 564-571.

${ }^{59}$ ALONSO, Dámaso. «Góngora y la nueva generación». Góngora y la literatura contemporánea. Madrid: Gredos, 1955, pp. 563-579 (pp. 565 y 579). 


\section{EXALTACIÓN DE TÉCNICA: LA METÁFORA}

El interés de los poetas del 27 por la dimensión lírica de la obra mironiana implica un interés principal por las cuestiones formales. Como vimos, Guillén hizo especial hincapié en el uso de Miró de cascada, del tipo: «El padre Bellod puso ratoneras en las hornacinas, en las esculturas, en los antipendios, en la escalera del órgano y de la torre» o «El azul, las paredes, las ropas, la piel, se penetraban de olor de azahar, de verbena, de cinamono, de eucaliptos, de pitas, de albahacas, de campánulas, de geranios calientes...» $(O C$, pp. 791, 800). Cabe suponer que el interés de Guillén por este recurso se debe a la sonoridad y ritmo que conlleva, y, con ello, a su proximidad formal a la poesía. ¿Hasta qué punto pudo influir Miró con este estilema en los poetas del 27? Se dan con frecuencia en Guillén ejemplos como: "Yo soy feliz en los árboles, / En el calor, en la umbría» o «Y la claridad reúne / Torres, sierras, nubarrones» ${ }^{60}$. También lo emplean Salinas («las puertas de la noche, / del viento, del relámpago ${ }^{61}$ ), Alberti ( Y en el agua, cabellos, flores, plumas ${ }^{62}$ ), y Diego ( «la brisa sobre el cristal / móvil, rizado, banal» o «El horóscopo adivina / obstinación, lucha, inquina ${ }^{63}$ ).

Son sólo unas pocas muestras, y el recurso no es exclusivo de Miró, con lo que no es concluyente. Pero lo que con este ejemplo quiere resaltarse es que Guillén, al hablar de las cascadas tan propias de Miró, fue a fijarse es en un rasgo formal, y uno que permite un nuevo lazo con Góngora por ser un elemento de técnica literaria. Las cascadas de elementos son, a todas luces, una forma de arquitectura poética, y, según dice Guillén, «para Góngora, la poesía, en todo su rigor, es un lenguaje construido como un objeto enigmático» ${ }^{64}$. Sin duda, y sin considerar ahora ese aspecto «enigmático», a Guillén no le pasaron desapercibidas las cascadas de Miró, ni dejó él de incluirlas en sus poemas, porque eran una forma de construcción lingüística (especialmente propicia para el poema). Lorca señalaba, por su parte, que «A Góngora no hay que leerlo, sino estudiarlo» ${ }^{65}$, modo de componer que requiere un lector atento, que desentrañe el senti-

${ }^{60}$ GUILLÉN, Jorge. Aire nuestro: Cántico. Clamor. Homenaje. Milán: All'insegna del pesce d'oro, 1968, pp. 61 y 73. En adelante, $A N$ más el n. ${ }^{\circ}$ de p.

${ }^{61}$ SALINAS, Pedro. Poesías completas. Barcelona: Lumen, 2001, p. 239. En adelante, PoCo más n. ${ }^{\circ}$ de $\mathrm{p}$.

${ }^{62}$ ALBERTI, Rafael. Poesía 1 (1920-1938). Madrid: Aguilar, 1988, p. 306. En adelante, $P 1$ más n. ${ }^{\circ}$ de $\mathrm{p}$.

${ }^{63}$ DIEGO, Gerardo. Poesía de creación. Barcelona: Seix Barral, 1974, pp. 19 y 27. En adelante, $\mathrm{PoCr}$ más n. ${ }^{\circ}$ de $\mathrm{p}$.

${ }^{64}$ GUILLÉN. Lenguaje, p. 35.

${ }^{65}$ GARCÍA LORCA, Federico. «La imagen poética de don Luis de Góngora». En: GONZÁLEZ MUELA, Joaquín; Rozas; JUAN MANUEL (eds.). La generación poética de 1927. Madrid: Alcalá, 1966, p. 244. 
do, muy en la línea del lector que, de acuerdo con la aspiración de Miró, ha «de ver poco a poco, por la virtud de la forma» ${ }^{66}$. Por esta común aspiración de forma, Guillén relacionaba a Miró y Góngora: «Muchos poetas hay [...] que ven en su idioma su mejor amigo. Así, por ejemplo, Góngora. Sin una gran fe en las palabras no las habría buscado y elegido con tanto fervor. Nadie gana en ese fervor y en esa fe, entre los españoles modernos, a un admirable lírico: el novelista Gabriel Miró (1879-1930)» ${ }^{67}$. Diego admira la prosa de Miró por ser «instrumento perfecto» ${ }^{68}$. Del mismo modo, los poetas del 27 reivindicaban una poesía de esfuerzo y elaborada, incluso aquellos que quisieron ser encasillados en lo popular y lo espontáneo del genio creador. Lorca reivindicaba que «si es verdad que soy poeta por la gracia de Dios —o del Demonio-, también lo es que lo soy por la gracia de la técnica y del esfuerzo» ${ }^{69}$. En última instancia, pues, lo que el 27 admira de Miró y de Góngora es su capacidad para trabajar arquitectónicamente el lenguaje: ambos habrían sido maestros del grupo por el virtuosismo de técnica literaria. De nuevo, se erige la idea de que Miró fuera un filtro, desde este punto de vista, entre Góngora y el 27. El propio Miró reconoció: «Góngora es el que llega a nosotros como un inmediato antecesor de nuestra técnica» ${ }^{70}$. A juicio de Macodonald, nosotros/ nuestra «surely refers not to the generation of 98 or to Ortega's generation, but to the poets of $1927 \gg^{71}$.

En el marco de esta exaltación de técnica literaria, es la metáfora el aspecto que más interesa tratar. En efecto, la afinidad más cercana entre Miró y el 27 se halla «al examinar su común apasionamiento por Góngora; no como lírico a imitar, sino como punto de inspiración para un lenguaje metafórico que busca dar suprarrealidad a lo sensible» ${ }^{72}$. Y es que, en pleno auge de las vanguardias, tanto Miró como el 27 hubieron de interesarse y se interesaron por este tropo. De hecho, Macdonald ha explicado que la metáfora fue precisamente una de las razones que más favoreció el paso de la concepción negativa de estilista a la más positiva de lírico, ya que el uso tan marcado de metáforas de Miró tenía necesariamente que ser mejor entendido en el ambiente creacionista y ultraísta, al que tan cerca-

${ }^{66}$ MIRÓ, Gabriel. Sigüenza y el mirador azul y Prosas de «El Íbero». KING, Edmund L. (ed.). Madrid: Ediciones de la Torre, 1982, p. 104.

${ }^{67}$ GUILLÉN. Lenguaje, p. 145.

${ }^{68}$ DIEGO. «Gabriel Miró», p. 203.

${ }^{69}$ GARCÍA LORCA, Federico. «De viva voz a Gerardo Diego». En: Poesía española contemporánea. Antología. Diego, Gerardo (ed.). Madrid: Taurus, 1962, p. 403.

${ }^{70}$ La referencia está recogida en una hoja suelta de papel que se ha conservado en el volumen XXXII de la BAE que poseía Miró en su biblioteca (Macdonald, Gabriel Miró, p. 57).

71 MACDONALD. Gabriel Miró, p. 58.

72 ALTISENT. «Miró, Salinas, Guillén», p. 34. 
nos estuvieron los poetas del $27^{73}$, en concreto Gerardo Diego. En efecto, de Miró se ha dicho que «percibe con metáforas, a través de metáforas, en metáforas. Su categoría estética es la metáfora» ${ }^{74}$. Y ya antes Diego había señalado que «Habría que estudiar [...] sus procedimientos retóricos, los secretos de sus imágenes» ${ }^{75}$.

Pero más que influencias directas en modos concretos de hacer metáforas, ha de entenderse que Miró fue un referente o escritor admirado por una común actitud metafórica, en el marco común de exaltación de técnica literaria. Y de nuevo ha de tenerse en cuenta la vinculación con Góngora. Emilio Orozco ${ }^{76}$ ha estudiado la metáfora en Miró poniéndola en relación con lo barroco y Góngora, mientras que Mariano Baquero definía el neomodernismo de Miró a partir de Góngora, especialmente por la «densidad metafórica» de ambos escritores ${ }^{77}$. La metáfora supone en Miró que la materia real «sea escamoteada y sustituida por la poética» ${ }^{78}$. Y esto es muy gongorino, pues en la poesía de Góngora «queda prohibido evocar una cosa mediante su simple nombre propio [...]. La realidad será aludida, y con estos rodeos y metáforas se irá creando una realidad mucho más hermosa ${ }^{79}$. Se trata, al fin y al cabo, del recurso metafórico por el cual el término real $\mathrm{R}$ es sustituido, sin dejar rastro, por el término imaginario $\mathrm{I}, \tan$ frecuente en Miró, y que en gran medida es resultado del «prurito [mironiano] por embellecer descriptivamente lo vulgar» de origen gongorino $^{80}$. Algo tan poco hermoso como el vello que tienen las ancianas en la cara (término real) se convierte «en pelusa de albérchigo» $(O C$, p. 163), y hasta el color putrefacto del herpes se convierte en granado en El obispo leproso: «sus mejillas granadas de herpes» $(O C$, p. 938)

Una concepción parecida comparten los poetas del 27. Si no este tan mironiano embellecimiento de lo vulgar, sí al menos esa actitud común a Góngora por la cual, «para Miró, observador poético, la realidad se metamorfosea tan pronto como la percibe, y en su visión la poiesis reemplaza

73 MACDONALD. Gabriel Miró, pp. 24-25.

${ }^{74}$ ANDERSON IMBERT, Enrique. «La creación artística en Gabriel Miró». En Crítica interna. Madrid: Taurus, 1960, pp. 229-246 (p. 241).

75 DIEGO, Gerardo. «Gabriel Miró», p. 203. Nótese, de nuevo, cómo un crítico posterior, como Anderson Imbert, no viene sino a repetir algo previamente destacado por un miembro del 27.

${ }^{76}$ OROZCO, Emilio. «La transmutación de la luz en las novelas de Gabriel Miró». En Paisaje y sentimiento de la Naturaleza en la poesía española. Madrid: Ediciones del Centro, 1974, pp. 153-172.

77 BAQUERO GOYANES, Mariano. «La prosa neomodernista de Gabriel Miró». En Prosistas españoles contemporáneos. Madrid: Rialp, 1956, pp. 173-253 (p. 244).

78 Ibidem, p. 246.

${ }^{79}$ GUILLÉN. Lenguaje, pp. 55-56.

${ }^{80}$ BAQUERO GOYANES. Loc. cit., p. 244. 
a la mimesis» ${ }^{81}$. Desde esta perspectiva, lo que Carlos Bousoño ${ }^{82}$, en relación al 27, llama imagen visionaria simple puede ser, sencillamente, una metáfora a la manera mironiana, bien por influencia directa de él, bien juntamente a través del magisterio de Góngora. Para Bousoño, la imagen visionaria simple es una correspondencia emotiva entre R e I. Tomemos este ejemplo de Sermones y moradas de Alberti:

... un amanecer de toros desangrándose a la boca de un túnel $(P 1$, p. 461),

Aquí, la correspondencia emotiva entre amanecer y toros desangrándose supone un contraste entre belleza y fealdad muy semejante a la práctica gongorino-mironiana que lleva a cabo la fusión imaginativa de dos elementos reales. La metáfora de Góngora funciona en muchos casos por una relación intelectual entre dos o más objetos dispares: «es la inteligencia con los sentidos quien tiende una red de relaciones entre los objetos [...]. De esta suerte ponen las imágenes en contacto objetos muy remotos entre sí» ${ }^{83}$. De la misma manera funciona el proceso asociativo-metafórico en Miró: una mujer, por «el pinchazo de un mosquito», se va «con un pomo de geranios en sus manos, y parecía que llevaba la sangre de sus dedos cuajada en flor» (OC, pp. 123-24). Miró, como Góngora, ha transformado una situación ramplona, de dolor insignificante, en algo sublime (un simple mosquito es capaz de crear una explosión de color), mediante la asociación de dos elementos que no tienen, en principio, relación alguna (el ramo de flores y la sangre de la picadura de mosquito). Alberti, lejos de crear un nuevo recurso metafórico de enrevesada nomenclatura (imagen visionaria simple), seguiría este mismo proceso de asociaciones común a Góngora y a Miró. Alberti, además, se vale de la misma estructura R de I que Miró («amanecer de toros» y «trozo de júbilo»), así como de un recurso de raíz mironiana, el gerundio adjetivo, del tipo «almendros subiendo por las laderas» o «geranios cerrando la redondez de la noria» ${ }^{84}$.

Pero si la presencia de Miró en el 27 en lo que a la metáfora se refiere está vinculada necesariamente a Góngora, lo está también al contexto epocal de las vanguardias, tan dadas en literatura a usar este tropo. Aquí, el nombre que ha de destacarse es el de Gerardo Diego, el poeta del grupo que tomó parte activa en el creacionismo. Parecería tentador suponer que hubo en él una influencia mironiana más concreta y fuerte. Nótese que Diego viene a confirmar la idea de Macdonald de que fue el aprecio de la

${ }^{81}$ MILLER, Yvette E. La novelística de Gabriel Miró. Madrid: Códice, 1975, p. 20.

${ }^{82} \mathrm{Me}$ refiero a las hipótesis de BOUSOÑO, Carlos. La poesía de Vicente Aleixandre. Imagen, estilo, mundo poético. Madrid: Gredos, 1956.

${ }^{83}$ GUILLÉN. Lenguaje, pp. 46-47.

${ }^{84}$ Uso del gerundio con función adjetival y ejemplos de Miró tomado de Kaul, «El estilo», pp. 123-124. 
vanguardia por la metáfora lo que favoreció una acogida más positiva de Miró, ya que, admirativamente, señala que en su prosa se da un «cincelado perfecto y un sentido poético, moderno y arbitrario del humor que le emparenta sin mengua de su singularidad con Jules Renard, Ramón Gómez de la Serna o los poetas de la imagen creacionista» ${ }^{85}$. Sin embargo, la huella de Miró en Diego no va más allá que ese tipo de confluencia estética (ampliamente, en su aprecio de técnica literaria, más concretamente en lo que a la metáfora concierte) con Miró y Góngora, al igual que los demás poetas del 27. Pero en algunos otros aspectos, también de tipo lírico-estilístico, pueden encontrarse una posible huella mironiana más particular. Lo cual no ha de sorprender. Añádase, a los datos ya ofrecidos, que Diego le mandó dedicado a Miró sus Versos humanos (1925), la obra precisamente por la que ganó el premio Nacional de Literatura por mediación de aquél, y que ya mucho más tarde siguió reconociendo su admiración por él en «Visitación de Gabriel Miró», poema «galardonado con la Flor Natural de los Juegos Florales celebrados en Alicante, el año $1951{ }^{86}$.

Se ha creído conveniente, para acotar y hacer más accesible el campo de estudio, centrarse en la poesía creacionista de Diego, reunida en Poesía de creación. Aquí, sus poemas de escenas campestres podrían recordar, aunque vagamente, a Miró, ya que, como se ha señalado, es el paisaje uno de los motivos mironianos por excelencia. En «Apunte», de Evasión, aparte del contenido (escena campestre), llama la atención el título, que parece evocar el tópico de Miró, sustentado por el 27, como mero escritor de estampas. Más significativo es el caso de «Ría»:

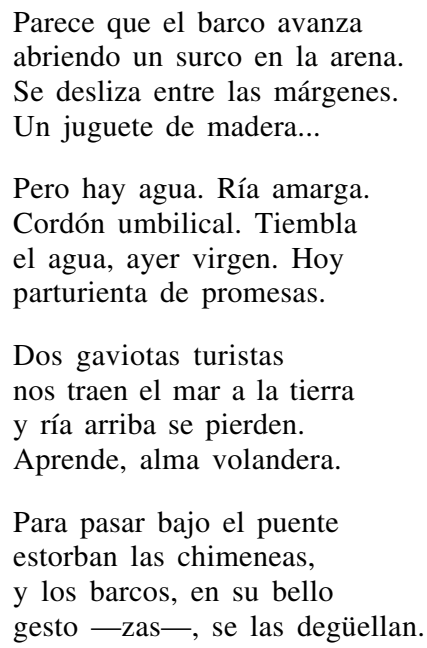

\footnotetext{
${ }^{85}$ DIEGO. «Gabriel Miró», p. 207.

${ }^{86}$ Cfr. MARTÍNEZ-MENA. Gabriel Miró, p. 58.
} 


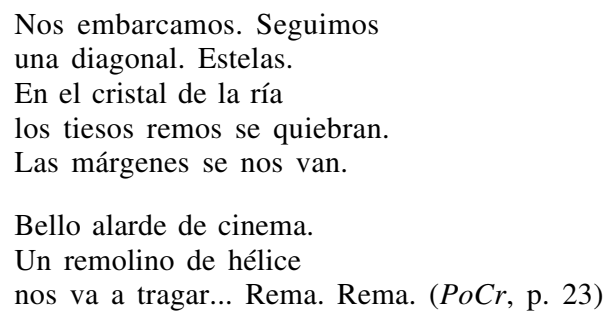

Destacan aquí algunos estilemas típicos de Miró, como la supresión de verbos en forma personal a favor de estructuras nominales ${ }^{87}$. Compárese el poema con estas palabras de Miró: «Un contacto de creación desnuda que calaba la piel y la sangre. Carne de alma, y el alma como una ola comba, vibrante, dolorida y gozosa de doblarse y distenderse, pero hincada en la peña. Sensación olorosa de firmamento. La mirada y el afán cogidos en nuestra vida, y alejándose encima de las aguas, tocándolas sin tropiezo, como alciones hermanos» $(O C$, p. 757). Puede verse que tanto en Miró como en Diego la ausencia de verbos favorece la abundancia de comparaciones y metáforas, así como estructuras calificativas con $d e$. El verso de Diego «parturienta de promesas» (segunda estrofa) está muy cerca de las frases tan mironianas como «El río estrecho y centelleante de sol» o «jardín bravío, impetuoso de ramaje» (OC, pp. 94 y 280). Otro recurso muy mironiano en la misma línea es la sinécdoque sintáctica, que consiste, como veremos al tratar de Guillén más adelante, en suprimir los elementos sintácticos para acercar los otros considerados más importantes, y en los que, por tanto, se sostiene la significación. Así en este verso del citado poema de Diego: «tiembla el agua, / ayer virgen», en el que se suprime la construcción de relativo («que ayer fue»); o en «Seguimos / una diagonal. Estelas», en el que no se sabe si se trata de una comparación («diagonal como estelas») o una enumeración asindética («diagonal y estelas»). (Compárense estos ejemplos con los que de Miró se darán al estudiar su influencia en Guillén en torno a la sinécdoque sintáctica). Por otra parte, el poema nos recuerda, por su temática, a los capítulos de «Muelles y mar» de El libro de Sigüenza ${ }^{88}$ :

Era una mañana inmensa de oro. Lejos, encima del mar, el cielo estaba blanco, como encanecido de tanta lumbre, y las paradas aguas, que de tiempo en tiempo hacían una blanda palpitación, ofrecían el sol infinitamente roto. Si pasaba una lancha, silenciosa y frágil, los remos, al emerger, desgranaban una espuma de luz.

\footnotetext{
${ }^{87}$ KAUL. «El estilo», pp. 119-123.

${ }^{88}$ La relación es oportuna. Además de ser una de las obras más citadas por el 27, cronológicamente tiene sentido. El libro de Sigüenza fue publicado en 1917, sólo un par de años antes que el libro de Diego, si bien la mayoría de sus partes habían aparecido en prensa con anterioridad, con lo que es seguro que Diego ya las había leído.
} 
Gritaban las gaviotas delirantes de alegría y luz. [...]

De todos los barcos escogió Sigüenza para mirar un vapor negro [...]. Respiraba un hondo hervor de máquinas. Sus grúas eran palos gigantescos que se torcían sobre la tierra... (OC, p. 589).

En «Emigrante» $(\mathrm{PoCr}$, p. 135), Diego mezcla las huertas - motivo tremendamente mironiano ${ }^{89}$ - con el mar - espacio al que Miró también se refiere a menudo- Hay, en el poema, además, «espumas» (palabra repetidísima por Miró, de la cual hay un ejemplo en el texto anterior) «chafadas» (estilema léxico mirononiano) ${ }^{90}$.

Finalmente, en «Aldea» (publicado en 1922), Diego parece resumir los motivos de las «Estampas rurales» de El ángel, el molino y el caracol del faro (1921) de Miró. Una de las estampas de esta obra se titula de la misma manera que el poema: «La aldea». Aparecen también en el poema de Diego un pastor (una estampa de Miró se llama «El águila y el pastor»), un molino (otra estampa mironiana es «El molino») y un campanario. En toda la obra de Miró, pero en especial en la estampa de El ángel que lleva su nombre, «Las campanas» son símbolo de tiempo, «porque vibra en ellas el tiempo» $(O C$, p. 742), y así parece serlo también para Diego: «Del campanario va a volar el día» $(\mathrm{PoCr}, \mathrm{p} .149)$.

\section{MiRó, SALINAS Y GUILLÉN}

La relación entre estos tres autores es la más estrecha, como han apuntado Altisent y Díez de Revenga, y según queda reflejado en el epistolario Miró-Guillén. Éste se refiere a Miró como «maestro»; en otra carta, Miró llama a Guillén «hijo mío», mientras que en otra parte afirma Miró: «Voy creyendo que es usted más Sigüenza de lo que usted imagina» ${ }^{91}$, en referencia a las primeras críticas de Cántico (primera versión publicada en 1928). No es baladí que Miró tuviera en su biblioteca un ejemplar dedicado de este libro ${ }^{92}$. Aquí, Guillén encabeza el poema «Jardín en medio»con

${ }^{89}$ Muy acertadamente lo comenta Pedro de Lorenzo: «Miró es huerto» (Obras completas. Madrid: Editora Nacional, 1974, I, p. 308); «Si Azorín ha interpretado, cumplidamente, la huerta murciana, para la huerta alicantina Gabriel Miró» (Obras completas. Madrid: Editora Nacional, 1976, III, p. 760).

${ }^{90}$ Hay ciertas palabras que Miró no se cansa de repetir. De todas ellas, el más conocido es «cráneo», en sustitución de «cabeza» («El cráneo del enfermo comenzó a removerse», $O C$, p. 830), pero tiene una gran presencia «chafado», que usa a menudo para describir las pústulas de la lepra: «Sus pies chafados, grandes, torcidos» (OC, p. 13), o como sinónimo de aplastar: «los aborrecía y los chafaba» $(O C$, p. 739).

${ }_{91}^{1}$ GUILLÉN. En torno, pp. 109, 121 y 128.

${ }_{92}$ Por ser la obra más importante de Guillén y porque la empezó a escribir en vida de Miró, me centraré para mi análisis en Cántico, obra a la que Miró alaba de este modo: «Querido Jorge Guillén: ya le habrán dicho todo eso de la perfección de su «Cántico»» (GUILLÉN. En torno, p. 140). 
una cita de Miró. La composición reúne rasgos estilísticos típicamente mironianos: el uso ya mencionado de cascadas de palabras («Azoteas, torres, cúpulas», $A N$, p. 62), así como el de diminutivo ${ }^{93}$ y de sintagmas nominales sin actualizar ${ }^{94}$ («Buches se adivinan fatuos, / Grosezuelos», $A N$, p. 63). A nivel de temas, el título del poema es muy representativo, dado el gusto mironiano ya señalado por los huertos y los jardines como lugar de retiro y paraíso terrenal, el tópico del hortus conclusus $^{95}$ que Guillén evoca al exclamar: « $¡$ Oh soleada clausura!» $(A N$, p. 63) y al definir el jardín como «paraíso» y «paz sin dueño» $(A N$, p. 64).

El triángulo amistoso lo pone de manifiesto Miró en otra carta a Guillén: «Aquí estuvo el profesor Salinas. Conversamos de usted. Recordamos nuestra tarde aldeana en la Casa de Campo» ${ }^{96}$. Miró se refiere a $« \mathrm{Mi} \mathrm{Pe}-$ dro Salinas» como al «maestro de la Víspera del Gozo» ${ }^{97}$. Según Altisent, Salinas escribió Presagios (1923) y Víspera del gozo (1926) compartiendo las lecturas de Años y leguas con Miró en los veranos en Alet, Alicante ${ }^{98}$. Nótese que Miró tuvo en su biblioteca ejemplares dedicados de estos dos libros de Salinas, así como de Seguro azar (1929).

${ }^{93}$ Véase MIRÓ, Gabriel. El obispo leproso. Ruíz-Funes (ed. e Introd.). Madrid: Cátedra, 1989, pp. 15-113, especialmente pp. 99-10, en que se aprecia el uso tan mironiano del sufijo —zuelo («bestezuela», «pedrezuelas») que es el mismo que va a emplear Guillén en el ejemplo; véase también BAQUERO, GOYANES, Mariano. Perspectivismo y contraste (De Cadalso a Pérez de Ayala). Madrid: Gredos, 1963, especialmente las pp. 132-139, dedicadas al uso del diminutivo en Miró y Azorín. He aquí algunos ejemplos de Miró: «cercadillos de piedras viejas»; «le sacaba algún insectico»; «lo más nudoso y negro de las cepas abuelas se alborozaba con sus netezuelos»; «Doña Beatriz partía con sus dientes un pedacito de pan»; una «rapazuela muy graciosa»; «La manta dobladita; el cestillo de la comida, muy lleno, limpio y oloroso» (OC, pp. 4, 88, 94, 345, 363, 407).

${ }^{94}$ Esto es, sin artículos, como en «Cruzaba $\varnothing$ pueblos [...]. A las puertas de las casas, $\varnothing$ mujeres tejían $\varnothing$ medias; trenzaban $\varnothing$ pleita de palma o soga de esparto; peinaban a $\varnothing$ rapazas greñudas» $(O C$, p. 3$)$. Sobre la presencia/ausencia del artículo en las enumeraciones mironianas, véase RUÍZ-FUNES, loc. cit., pp. 94-96.

${ }^{95}$ Léase COOPE, Marian G. R. "Gabriel Miró's Image of the Garden as «Hortus Conclusus» and «Paraíso Terrenal»». Modern Language Review, 1973, 68, pp. 94-104. He aquí un ejemplo de Miró, tomado de Dentro del cercado, título que refleja precisamente el tópico del hortus conclusus. Justo ha muerto la niña a la que se llama Corderita, y Luis se encuentra con Laura en el huerto, consolándola: «Los brazos de Luis la ampararon bajo los olorosos árboles del huerto»; frente a la tristeza de la muerte, Luis se siente henchido de amor por Laura: "Sentía que penetraba en su espíritu y la gozaba en posesión sin pecado; él, sólo él había llegado al escondido jardín de su alma. [...] Luis la besó» (OC, p. 290).

${ }^{96}$ GUILLÉN. En torno, p. 111.

${ }^{97}$ Ibidem, pp. 120 y 127.

${ }^{98}$ ALTISENT. «Miró, Salinas y Guillen», pp. 17-18. 


\subsection{Exaltación de la palabra}

Gerardo Diego ya puso de manifiesto «el poder mágico que la palabra posee para Miró» ${ }^{99}$. Sin embargo, es Guillén el que más ha profundizado en este aspecto, desarrollando en Lenguaje y poesía toda una teoría sobre la exactitud del lenguaje mironiano, como ya se resumió más arriba. Por ello, y por todo lo que se dijo en torno a la exaltación de técnica, no sería extraño encontrar la huella de Miró a nivel estilístico. De hecho, Johnson explica el recurso mironiano que llama sinécdoque sintáctica, y lo pone en relación con Guillén:

se suprime una parte del sintagma y se deja que otras partes lleven el peso del sentido [...]. Se eliminan algunos aspectos puramente lingüísticos de la frase para acercar las cosas y sus propiedades en el sintagma. Por ejemplo, en la frase «Por las ventanitas del comedor pasaban ráfagas de inmensidades azules; el cielo convertido en ave», se suprimen las conexiones gramaticales y se altera la sintaxis para dejar nada más los elementos esenciales que luego el lector tiene que interpretar. La unidad «el cielo convertido en pájaro» que lógicamente se relaciona a «ráfagas de inmensidades» en forma de símil —el cielo es como un pájaro que vuela por la ventana- queda al final separado por punto y coma sin conexión lógica con el resto de la frase. ¿Aprendió esta técnica Guillén («todo en el aire es pájaro») en la obra de Miró? Es muy posible ${ }^{100}$.

La sinécdoque sintáctica parece coincidir con lo que Marcus Parr llama apóstrofe, que se da cuando «Miró emplea palabras aisladas y frases cortas, con verbo implícito y mostrando poco o ningún acorde sintáctico con el contexto», como en «Ascuas de terrones. Crujidos de aristas. Estridor de cigarras» ${ }^{101}$. Ya sea apóstrofe o sinécdoque sintáctica, el recurso es muy frecuente en Miró, y se usa para lograr la yuxtaposición de imágenes. Por la ausencia de nexos gramaticales que guíen la lectura en un único sentido lógico de interpretación, la capacidad metafórica se multiplica:

Por la tarde, me tomó el viejo de la mano para bajar la cuesta de la playa.

Peñas de herrumbre, con cicatrices de pechinas; matas duras, afiladas de dedos que dan un zumo de sabor de petróleo; cantizal y arena. En lo hondo, aduares de pescadores, con las sendas negras de las redes tendidas; sogas enrolladas; nasas viejas sirviendo de jaulas a las crías de una gallina clueca. (OC, p. 771)

De forma parecida, aparte de en el verso ya citado por Johnson de «Todo en el aire es pájaro», escribe Guillén ejemplos parecidos: «¿Y las rosas? Pestañas / Cerradas: horizonte / Final. ¿Acaso nada?», «Manantial, doncella: / Escorzo de piernas, / Tornasol de guijas», «Divino: presentir / Casi desde la nada» ( $A N$, pp. 36, 46 y 79).

\footnotetext{
${ }^{99}$ DIEGO. «Gabriel Miró», p. 204.

100 JOHNSON. El ser, p. 163.

${ }^{101}$ MARCUS PARR. «El concepto modernista de la palabra en Miró». Hispania, 1956, 39, pp. 68-71 (p. 70).
} 
Sin embargo, la presencia de Miró en Guillén, en lo que a la palabra se refiere, es más temática que estilística, pero no por ello menos relacionada con el tópico lírico. Prácticamente todos los aspectos estudiados por Guillén en Lenguaje y poesía en torno a la palabra-lenguaje de Miró están en su propia poesía. Claro que aquí es preciso abordar de nuevo el problema de la influencia. Guillén lee a Miró a la luz de su personal filosofía de la palabra, y ve realizados en él sus propias concepciones poéticas. En este sentido, Guillén no pone en práctica el tema mironiano de la palabra directamente, sino el modo como él lo ha entendido y según él lo ha definido. La huella temática de Miró en Guillén está filtrada en gran medida por el propio Guillén, de modo que no es tanto Miró lo que se proyecta en la obra de Guillén, como la lectura guilleniana de aquél.

No obstante esta matización, el tema de la palabra cobra tal importancia, que abre y cierra, en sendas dedicatorias, el Cántico de Guillén. La dedicatoria introductoria está dirigida a su madre porque «mi lenguaje me regaló, el lenguaje que dice ahora con qué voluntad placentera consiento en mi vivir, con qué fidelidad de criatura humildemente acorde me siento ser» $(A N$, p. 21), lo que enlaza directamente con la consideración guilleniana de que para Miró «el hombre llega a ser hombre merced a la expresión» ${ }^{102}$. Lo mismo se expresa en la dedicatoria final, a Salinas, a quien describe como ávido «de consumar la plenitud del ser en la fiel plenitud de las palabras» (AN, p. 537). La noción mironiana, ya citada, de que «La palabra es la misma idea hecha carne» parece estar detrás de esta interpretación del ser y la expresión en estos versos guilleneanos de «Salvación de la primavera»: «Por tu carne / La atmósfera reúne / términos. Hay paisaje» $(A N$, p. 104 . De forma parecida puede entenderse «la carne expresa más. Somos nuestra expresión» (AN, p. 106).

Altisent ya ha estudiado cómo en Guillén y en Salinas se pone en práctica la concepción mironiana de que nombrar es crear ${ }^{103}$, y cómo nombrando se ilumina (de ahí la metáfora de la luz) la realidad. Pone esto en relación con el famoso pasaje mironiano, citado a su vez por Guillén en Lenguaje y poesía:

[...] hay emociones que no lo son del todo hasta que no reciben la fuerza lírica de la palabra, su palabra plena y exacta. Una llanura de la que sólo se levantaba un árbol, no la sentí mía hasta que no me dije: «Tierra caliente y árbol fresco». Cantaba un pájaro en una siesta lisa, inmóvil, y el cántico la penetró, la poseyó toda, cuando alguien dijo: «Claridad». (OC, p. 692)

${ }^{102}$ GUILLÉN. Lenguaje, p. 146.

${ }^{103}$ ALTISENT. «Miró, Salinas y Guillén», pp. 24-31. Influido por esta lectura, Edmund L. King señala que Miró «va creando [las cosas] a medida que va sensacionándolas, conceptuándolas y nombrándolas». Véase «Gabriel Miró y «El mundo según es»». En: VILLANUEVA (ed.). La novela lírica. Madrid: Taurus, I, 1983, pp. 205-216 (p. 213). 
De la misma manera, Guillén exclama: «La palabra / Difunde su virtud reveladora» (AN, p. 400). En el poema «Más allá», los objetos «Nombrados, / Se allanan a la mente» (AN, p. 30). En «Paso a la aurora», el yo lírico expresa su júbilo porque «Todo, por fin, se nombra» (AN, p. 121), mientras que el nombre se pone bajo la luz en «Sábado de gloria»: «Todo a tanta luz se nombra» (AN, p. 133).

Miró, de acuerdo con Guillén, demostraría que la conciencia del mundo y la autoconciencia se derivan del acto de nombrar: «La "conciencia de las cosas" — cree Miró- se nos da "bajo la palabra". La conciencia de las cosas y de los sentimientos. Sigüenza, alter ego de Miró, "se ha oído a sí mismo pronunciar 'seamos dichosos'. Y al decirlo comenzaba a serlo... Porque en aquellas palabras había un principio de voluntad y de conciencia de la dicha"» ${ }^{104}$. Paralelamente, Guillén escribe: «Yo lo soy si le nombro / Con toda mi sorpresa» $(A N$, p. 369). En otra ocasión se autoafirma por su cualidad de homo loquens: «Porque de veras soy, de veras hablo» ( $A N$, p. 402$)$; y termina preguntándose: «¿El hombre es ya su nombre?» ( $A N$, p. 404). No es sólo que la palabra sea herramienta de (auto)conciencia, sino que en Miró «el acto contemplativo se realiza del todo gracias al acto verbal» ${ }^{105}$; del mismo modo en «Los nombres» Guillén dice: «Y empiezo a ver. ¿Qué? Nombres» (AN, p. 36). En «Luz natal», el cerro San Martín «a través de su nombre se divisa» (AN, p. 348).

También Salinas asume esta temática en su poesía. De acuerdo con las reflexiones que hacíamos antes, uno no puede dejar de preguntarse hasta qué punto en Salinas este tema es deudor de Miró o de Guillén. Cualquiera que sea el modus operandi del proceso de influencia, la presencia de este tema en la poesía se Salinas pone de manifiesto el estrecho contacto literario entre los tres autores.

La posesión de la amada se debe a la posesión del nombre y a la gracia de su pronunciación:

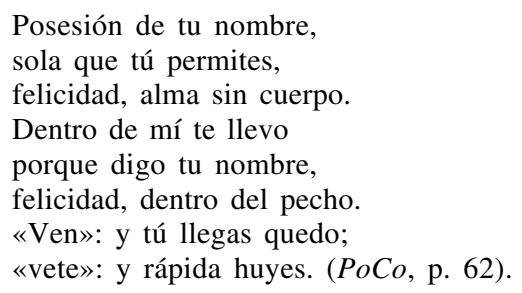

La contemplación del solo nombre de un barco hace que Salinas le invente toda una historia: "Manuela Plá" se llama el barco. / Manuela Plá será sin duda el nombre / de la viuda del armador...» (PoCo, p. 93).

\footnotetext{
104 GUILLÉN. Lenguaje, p. 148.

105 Ibidem, p. 146.
} 
También Miró hace que Sigüenza invente una historia, luego desmentida por los hechos, para el barco Dagphin-Kristiania en «Una noche (En Cristiania)» de Libro de Sigüenza (OC, pp. 594-598). En otra ocasión, pronunciar «agua» (elemento de tanta importancia en Miró ${ }^{106}$ ) permite sentir sus cualidades: «La palabra postrera de la enferma fue: «Agua». / Y se sintieron saltos cantarines de arroyo...» (PoCo, p. 105), de la misma manera que Sigüenza «Pronunciaba «acanto, acanto», y la dorada Grecia se le presentaba dulce y risueña delante de su alma y de la planta» $(O C$, p. 615). Como la palabra de Miró, idea hecha carne, nombre - pronunciado- e idea parecen ser una misma cosa, en Salinas, para representar al mar:

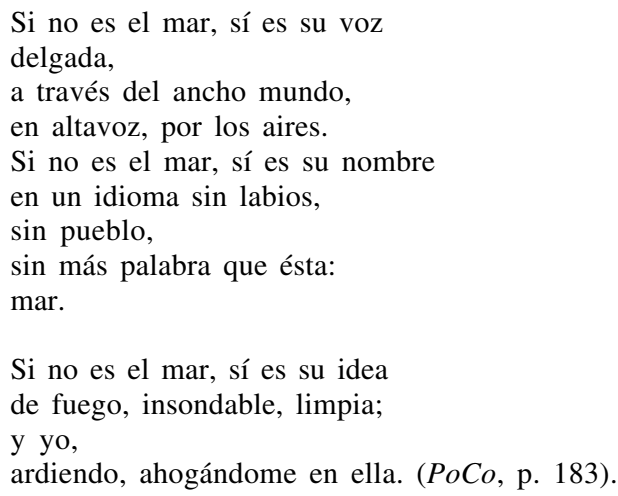

Una palabra es protagonista de un poema de La voz a ti debida, palabra muerta hasta que la pronuncia la amada, y entonces, como al pronunciar «agua», se produce un torrente de sensaciones, que son, no azarosamente, carne:

\author{
«Mañana». La palabra \\ iba suelta, vacante, \\ ingrávida, en el aire,
}

\footnotetext{
${ }^{106}$ Para la importancia del agua en Miró, léase RAMOS, Vicente. El mundo de Gabriel Miró. Madrid: Gredos, 1970, especialmente la sección «Teoría del agua», pp. 250-269. Tómese como ejemplo este pasaje de Miró, en el que el mismo elemento obtiene diferentes sentidos, complementándose bajo el significado común del agua como evocación/recuerdo: «El agua del bernegal nos hace sentir al lado toda la fuente del pueblo [evocación]; la de la cuesta con el ruido de los once chorros dentro del ruido alto de los grandes follajes de los álamos [oído]. Manan los caños en la pila morena y larga del abrevadero y lavadero. Vienen y vuelven las mozas con los cántaros acostados o rectos sobre su frente nazarena [lo femenino]; niñas en filas, con los cántaros cogidos de la mano como criaturas [infancia] [...] Suenan más puros y más frescos los caños en el atardecer [pureza] [...] Olor íntimo del agua que toca las raíces profundas en la tierra tan tierna como un fruto descortezado; olor del agua desde el tiempo [olfato]. Como en todas partes; es verdad; pero en cada pueblo su olor. El de la fuente del pueblo donde está Sigüenza, el suyo, el mismo que recogió Sigüenza en otros años, que era el mismo de siempre [evocación a través del agua-olor]» $(O C$, p. 1123).
} 


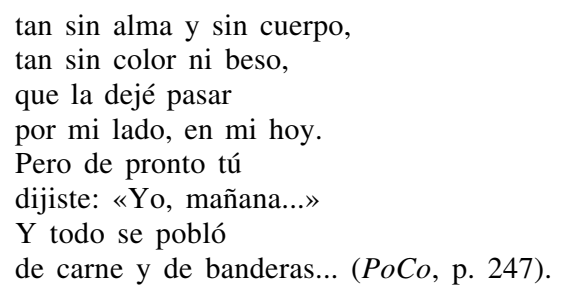

La conciencia del mundo y la autoconciencia también se asumen por la palabra:

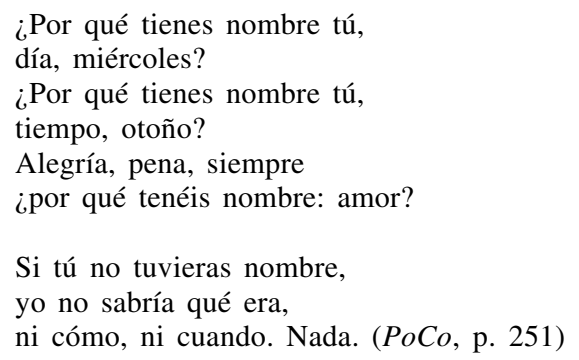

Pero la palabra debe ser expresada por alguien en particular. Según Guillén, a Miró «le complace oír los nombres de los pueblos pronunciados en los pueblos mismos por sus propios habitantes para hondar lo más posible en el compacto y jugoso terrón de lo más concreto» ${ }^{107}$. Sólo así el nombre cobra su plenitud, como el concepto de amor entre los amantes de Salinas, e incluso la plenitud del ser de la amada, que sólo cobra sentido en labios de su amante:

¿Tú sabes lo que eres

de mí?

¿Sabes tú el nombre?

No es

el que todos te llaman,

esa palabra usada

que se dicen las gentes,

si besan o se quieren,

porque ya se lo han dicho

otros que se besaron. [...]

Y así, lo que tú eres,

cuando yo te lo digo

no podrá serlo nadie,

nadie podrá decírtelo. (PoCo, pp. 390-91)

${ }^{107}$ GUILLÉN. Lenguaje, p. 150. 
Queda aún un tema: la palabra como medio de colmar el vacío de la ausencia de la amada. Explica Guillén, de Miró, que «cuando el enamorado piensa en la amada ausente, la imagen de la ausente incorpora ante todo palabras» ${ }^{108}$, como en este pasaje de El obispo leproso:

Ella también miraría el agua, los árboles, el cielo, y diría: río, árbol, cielo. Cuando saliesen los palomos de su terrado [...] ella los vería y pronunciaría: palomos, aire, sol... Así se afanaba Pablo en pensar y regalarse con las palabras que María Fulgencia tuviera en sus labios [...]; y, repitiéndolas, participaba de su pensamiento, de la acomodación de su lengua, de sus actividades interiores, coincidiendo sus vidas. (OC, pp. 1036-1037).

La amada de Guillén en «Su persona» se evapora en recuerdo, que es, evocando El humo dormido de Miró, «Humo a capricho del aire» ( $A N$, p. 502). Esa ausencia dolorosa, recordada, se hace más dulce al hacerse carne con la palabra: «Apunta una tentativa / De carnación» (AN, p. 503). La ausencia se subsana gracias a la palabra literaria: «Lo inasequible a los ojos / Con tal arte se revela / Que envuelve en un falso estío / Para sofocar de veras» (AN, p. 504).

También Salinas hace coincidir las vidas de los amantes en la distancia a través de la palabra, en su archiconocido poema «iQué alegría, vivir». El poeta camina con los pasos de la amada, mira con sus ojos y dice sus mismas palabras: «Que hay otra voz con la que digo cosas / no sospechadas por mi gran silencio; / y es que también me quiere con su voz» ( $P o C o$, p. 276). Y en otro poema, la ausencia de la amada se suple con las palabras de ésta, «no te vayas», que lo protegen de otras voces:

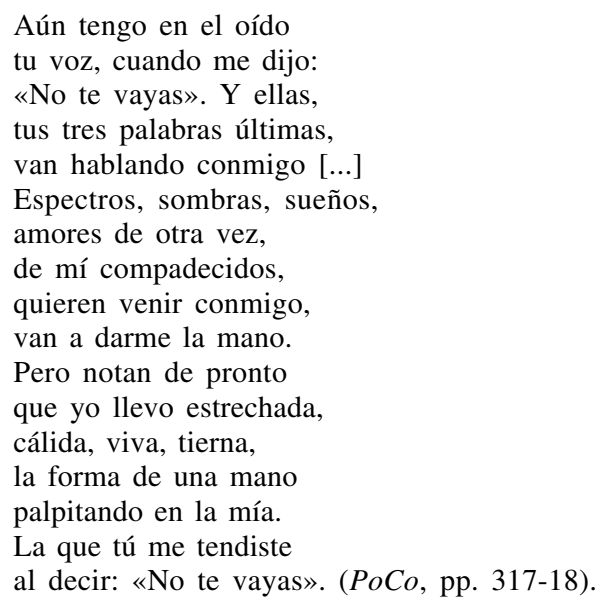

${ }^{108}$ Ibidem, p. 149. 


\subsection{Exaltación del paisaje y sensualidad}

Como ya se vio al principio, el 27 contribuyó a fomentar la imagen del Miró paisajista. A esta consideración, Salinas habla de que en Miró se produce una forma no material de posesión: «la clave de la actitud espiritual de Miró y de su arte literario» ${ }^{109}$. No es una posesión en sentido de propiedad, sino una posesión espiritual, que nace del vínculo sensual con el paisaje: «Nuestro aventurero se apodera del mundo con sus cinco sentidos» ${ }^{110}$. Más tarde, la crítica ha reincidido en el tema: «La propiedad en el sentido sigüencista significa convergencia anímica y sinfronismo total, que nada tienen que ver con legajos ni títulos de propiedad» ${ }^{111}$. Así lo ejemplifica este pasaje del Libro de Sigüenza:

¿Es que la idea de dicha es una idea de propiedad? Parece que sí; de propiedad, no de propietario. Las manos, todas las manos, las tiernas, las blancas y pulidas, las cortezosas, las fuertes, las seniles, tienden a coger; el alma, a tener, a poseer. No de agarrar. Agarran los amos que no son más que eso: amos, amos de dinero, de haciendas [...]. Y esos son los que menos poseen: son propietarios. (OC, pp. 648-649)

Recuerdan estas manos, que buscan una posesión espiritual, no material, la mano de ciego de Salinas, que se guía por el tacto, el sentido que Salinas considera más importante en Miró. Y es una mano que no agarra y que busca más allá:

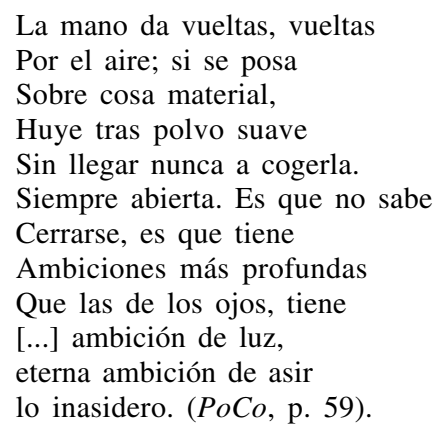

En otro poema, Salinas puede poseer, por la sensualidad de su sombra y del jugo de sus frutos, el naranjo ${ }^{112}$, que el propietario ha vaciado mate-

109 SALINAS. «Prólogo», p. ix.

${ }^{110}$ GUILLÉN. Lenguaje, p. 154.

${ }^{111}$ LANDEIRA, Trilogía, p. 106.

112 Otro cítrico tiene una fuerza sensual muy marcada en Miró: el limón. Recuérdese la escena más significativa de este tema en El obispo leproso, en que María Fulgencia le lava a Pablo las manos con el jugo del limón, impregnándolo de su perfume (OC, pp. 10351036). Esta escena es posterior al poema citado de Salinas, pero el limón aparece desde 
rialmente: «Hoy te han quitado, naranjo, / todas las naranjas de oro» (PoCo, p. 80). En cierto momento, Salinas mira el paisaje avaramente: «lo que cogen los ojos / con torpe prisa de avaro». Se trata de un tipo de avaricia que recuerda la de Sigüenza:

Miraba y aspiraba este hombre con tanto ímpetu, que llegó a sentir cansancio y dolor de su carne. Y nunca se saciaba, sino que le parecía que le faltaba tiempo para hundir sus ojos en aquellas hermosuras y recoger toda la vida que se le ofrecía desde el alto camino. (OC, p. 631).

El «Paisaje en medio» de Guillén es una «paz sin dueño» (AN, p. 64), pero eso no impide que clame por la posesión del paisaje: «Dame el campo con el cielo, / Dámelos», «...Quiero más!» (AN, p. 67); «¡Ya es mía, ya es mía!» (AN, p. 89). Posesión que es casi una rendición. Según Salinas, el sensualismo de Miró es fruto de «la condena de ser vencido por lo terrenal. [...] Todo se lo comerá la tierra, seremos poseídos por ella. Y oscuramente sintió [Miró] que la única manera de vencerla era ésa, poseer a la tierra antes» ${ }^{113}$. También Guillén se apodera de la naturaleza, rindiéndose a ella:

\footnotetext{
Rendición: relieves. ¡Qué míos, qué puros

Todos! Uno a uno

Resaltan, ascienden.

$[\ldots]$

Posesión: relieves.
}

\subsection{Otros temas}

El poema «Estación» (PoCo, p. 202) de Salinas, que por el título evoca el mironiano motivo del tren, describe una ciudad de tal modo que bien pudiera ser Oleza ${ }^{114}$, por varias razones: (i) porque, «nunca vista», tal vez sea una ciudad ficticia, como lo era aquélla; (ii) por su «ausencia con tres sílabas» (tres son las sílabas de Oleza); (iii) por «su obispo y su casino» (Oleza es el espacio de El Obispo leproso), y (iv) porque es una ciudad que refleja a otra real, «amarrada a sus siglos» (Oleza es la representación literaria de Orihuela).

muy pronto en la obra mironiana, por lo que no es inverosímil que Salinas lo tuviera en mente a la hora de componer este poema. Para más información sobre el motivo del limón en Miró, véase O'SULLIVAN, Susan. «Watches, Lemons and Spectacles: Recurrent Images in the Works of Gabriel Miró». Bulletin of Hispanic Studies, 1967, 44, pp. 107-121.

113 SALINAS. «Prólogo», p. xx.

${ }^{114}$ La relación es cronológicamente plausible. El poema pertenece a Fábula y signo (1931), mientras que las novelas de Oleza datan de 1921 y 1926. Para ejemplificar que el tren es un motivo mironiano, recuérdese el tren que llega a Oleza, y que es prácticamente el núcleo en torno al cual se construye la trama de El obispo leproso. 
Tanto Salinas como Guillén parecen asumir la noción tópica de Miró como autor de estampas de tiempo detenido. Tiempo asociado al espacio descrito (como testimonia el título de una de las obras de Miró, Años y leguas), que conforma un presente eterno. Así lo explica Guillén: «A Miró se le incorpora el pasado a su visión actual y así lo contempla: pasado y presente, pasado fenecido dentro del minuto que trascurre» ${ }^{115}$. En «Las soledades interrumpidas», título de por sí muy mironiano, espacio y tiempo se funden desde el principio:

Hay robles, hay nogales,

Olmos también, castaños.

Entre las muchas frondas,

El tiempo aísla prados. (AN, p. 42).

Y ese tiempo detenido sólo se ve precipitado hacia el futuro, como en Oleza, por el paso del tren:

\author{
Y se desgarra el tiempo... \\ Es el pitido súbito \\ De un tren que allí, tan próximo, \\ Precipita al futuro. (AN, p. 43)
}

A través de la contemplación del paisaje, se suscita el recuerdo, que funde presente con pasado, y provoca sensación de «rapto hacia mañana», conformándose un tiempo eterno en «Los tres tiempos» (AN, p. 51). De manera similar se expresa Salinas: «El futuro / se llama ayer»; « Retrocesos, en vértigo, / por dentro, hacia el mañana!» (PoCo, pp. 268-269). En la poesía de Guillén, el tiempo, además, parece detenerse en el paisaje: «Mayo sin prisa por Junio / Se abandona a su entretiempo» (AN, p. 62). Hasta tal punto se asocian tiempo y espacio, que «El tiempo quiere lugar, / Rechaza la hondura informe, / No acierta a vivir sin fondo / Que enamore» (AN, p. 71).

\title{
3. Miró, Alberti y Lorca. Cercanías
}

Mientras que la influencia de Miró en Salinas y Guillén es bastante sólida, dada la base de relaciones personales y escritos que sobre él ofrecen, en los casos de Alberti y, sobre todo, Lorca, es mucho más débil. Por ello, aunque todavía interesantes, me ha parecido conveniente referirme a cercanías, valiéndome de Alonso Zamora Vicente ${ }^{116}$.

${ }^{115}$ GUILLÉN. Lenguaje, p. 157.

${ }^{116}$ ZAMORA VICENTE, Alonso. «Gabriel Miró y García Lorca: visión de una cercanía». Lengua, literatura, intimidad. Madrid: Taurus, 1966, pp. 117-123. En este artículo, Vicente propone la confluencia de Miró y Lorca por un mismo tema, relacionado con la ciudad levítica. 


\subsection{Miró y Alberti}

Alberti homenajeó a Miró en «Balada con retorno de Gabriel Miró», donde parece reconocer su deuda: «Pero el agua que me ofreciste / refresca aún el alma mía» ${ }^{117}$. No puede decirse, empero, que exista una influencia directa, sino sólo confluencia, al coincidir con él en algunas revistas literarias y por el vínculo con Góngora. Alberti señala su colaboración con la revista Alfar, en la que también publicó Miró ${ }^{118}$. Su obra Giróscopo fue dada a conocer en primicia a Miró gracias a Juan Chabás ${ }^{119}$. Después de la publicación de aquella obra, Miró le mandó a Alberti una carta de felicitación. Las palabras de éste comentándola son muy significativas: «En Giróscopo — se me enreda el título (a él tampoco le complacía)— hay palabras de aguda belleza». Don adivinatorio de Miró, pues mi locura por el vocablo bello llegó a su paroxismo en el año del centenario de don Luis de Góngora, cuando con Cal y canto la belleza formal se apoderó de mí hasta casi petrificarme el sentido» ${ }^{120}$. Antes de Marinero en tierra (1925), aunque galardonada con el Premio Nacional de Poesía con el apoyo de Miró, no hay evidencia de que Alberti se interesara por aquél, por lo que la composición de este libro pudo hacerse sin conocer aún su obra. Es posible que la confluencia con Miró se suscitara a partir de la concesión del premio. Especialmente, en Cal y canto (1929), por ese fervor compartido (según deja entender Alberti en sus palabras antes citadas) de arquitectura literaria y por la palabra.

El limón es un motivo muy mironiano, con su destacada naturaleza sensual, como ejemplifica el famoso pasaje de El obispo leproso en el que Pablo se deja limpiar las manos con el jugo de un limón estrujado por su amada, María Fulgencio (OC, p. 1036). La misma sensualidad le da Alberti a esta fruta: «Pórticos de limones desviados / por el canal que asciende a tu garganta» (P1, p. 307).

Otro motivo, el tren, también representado en El obispo leproso (con el que viene el progreso a Oleza), Miró lo entiende como único elemento de tecnología que se funde armónicamente con el paisaje. En el siguiente ejemplo, paisaje y tren se funden bajo el común denominador de la tristeza de Sigüenza:

${ }^{117}$ ALBERTI, Rafael. Poesía 2. Madrid: Aguilar, 1988, p. 768. En adelante, P2 más n. ${ }^{\circ}$ de $p$.

118 ALBERTI. Arboleda, p. 153.

${ }^{119}$ Chabás fue un intenso admirador de Miró. Léase mi artículo «La influencia de Miró en Sin velas, desvelada, de Juan Chabás: Ensoñación lírica y desengaño». En: REGUEIRO SALGADO, Begoña y RODRÍGUEZ RODRÍGUEZ, Ana $\mathrm{M}^{\mathrm{a}}$ (eds.). Lo real imaginado, soñado, creado. Realidad y literatura en las letras hispánicas. Vigo: Editorial Academia del Hispanismo, 2009, pp. 446-456.

${ }^{120}$ ALBERTI. Arboleda, p. 156. 
[...] la tristeza se le incorporaba de todo lo que veía, porque la vega, sus humos, sus árboles, los montes y el cielo, todo estaba hecho de tristeza; la misma que le oprimía siendo chiquillo, cuando, vestido de uniforme de colegial, salía con su brigada, la de los pequeños, por aquellas sendas, aguardando el paso del tren, un tren que le traía tantas memorias alegres, que aún le entristecía más que el paisaje. $(O C$, p. 572).

Y el tren es capaz de evocar el campo: «Un tren nos presenta siempre evocaciones campesinas» $(O C$, p. 653). Alberti presenta el tren de manera muy parecida: «La música de riel y los heridos / montes dispersos, valles y piaras, / para los trenes de verano ardidos» ( $P 1$, p. 317). Desde el tren, Alberti exhorta a que se contemple con avaricia el paisaje, bebiéndolo: «En los viajes, / beba usted solo, con la vista, el viento / de los precipitados paisajes» $(P 1$, p. 324). En su «Carta abierta» a la poesía de Alberti, Luis García Montero señala que «pueden encontrarse, de igual forma que en casi todo el libro, ecos vanguardistas de alabanza al progreso urbano; pero al mismo tiempo surge una progresiva conciencia angustiada del estado de pérdida que este tipo de desarrollismo hacia el futuro está poniendo en marcha, al desarraigar, al desplazar las cosas de sus sitios naturales» ${ }^{121}$. El paisaje, vuelto al revés por el desarrollo («Hay peces que se bañan en la arena / y ciclistas que corren por las olas», $P 1$, p. 371), pero sin dejar de ser amado por sus cualidades estéticas, como en el cine ( $Y$ Yo nací — ¡respetadme!- con el cine. / Bajo una red de cables y de aviones», P1, p. 372). Miró también se preocupó mucho por este contraste entre progreso y conservación de la naturaleza. No es inverosímil que Alberti tuviera en mente pasajes como éste de Años y leguas ${ }^{122}$, en el que Sigüenza se queja de la destrucción de los campos, que «van trocándose en afueras»; Sigüenza, empero, reconoce las cualidades estéticas que los nuevos paisajistas ( ¿se refiere Miró al 27?, ¿a las vanguardias en general?) han descubierto:

Los nuevos paisajistas inician la acomodación de las presencias urbanas a su lírica. Y las antenas radiotelegráficas, las chimeneas industriales adquieren para sus ojos una dulzura de vigilancia civilizadora en los desamparos de la llanura, con exactitudes y categorías de imágenes literarias. (OC, p. 1121).

Para Sobre los ángeles, Alberti bien pudo estar pensando en «El ángel» de Miró (OC, pp. 742-46), ángel humanizado, que ha perdido las alas y fuma, ángel que ha sufrido por la falta de amor del ser humano y que sin embargo «goza aquí en la Tierra» $(O C$, p. 746). Este ángel mironiano se parece mucho a «El ángel desconocido», de Alberti:

${ }^{121}$ GARCÍA MONTERO, Luis. «La poesía de Rafael Alberti». En: ALBERTI. Poesía 1, op. cit., p. lxiii.

${ }_{122}$ Aunque publicado Años y leguas (1928) después que Cal y canto (1927), el pasaje citado está tomado del capítulo «Grandes señores», que había sido publicado con anterioridad en dos partes en La Nación, 18 de mayo y 8 de junio de 1924 (LANDEIRA. Trilogía, p. 114), por lo que Alberti seguramente hubo de conocerlo. 


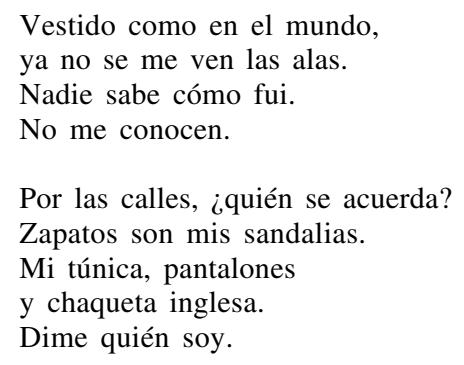

También Alberti se interesará, como Guillén y Salinas, por el problema mironiano de la palabra, el nombre y la pronunciación, como en su poema «Va diciendo una palabra / (oh, si yo la pronunciara!)» $(P 2$, p. 218), o cuando se preocupa de lo inapropiado de ciertos nombres para ciertos lugares: «iLos nombres! Feos y vulgares, casi todos. O los mismos de cualquier parte. Nombres, más bien, para calles o avenidas de la gran urbe». Se trata de nombres feos porque no se pronuncian con la gracia de su lengua de origen, el inglés: «Miami Park. (Maiami, si la caserita supiera algo de inglés)». Uno de estos nombres, bien pronunciado, es motivo de deleite: «Cantegril, sí [...]. El nombre más gracioso y fácilmente pronunciable entre todos los imposibles de la Punta del Este» $(P 2$, pp. 444445). Esta reflexión recuerda a la de «Toponimia» de Miró, en que, en vez de Sigüenza quejarse por la torpeza, se deleita por la correcta dicción de los nombres de los lugares, nombres valencianos: «Y estos nombres rurales en boca de sus gentes dejan un sabor de fruta [...]. Allí, sólo allí se puede pronunciar íntegramente el nombre de cada pueblo. Fonética valencia de Alicante». Más tarde, Sigüenza, como hace Alberti, corrige la mala pronunciación, que se debe al desconocimiento de la lengua: « $\mathrm{Si}$, por ejemplo, se pronunciara Famorca con la «o» cerrada y breve de Castilla, Famorca no significa más de una noticia de diccionario geográfico. Pero con la «0» grande, rotunda, la «o» exacta y verdaderamente central y valenciana, Famorca adquiere una legítima arquitectura silábica» (p. 1134).

\subsection{Miró y Lorca}

Lorca es el único de de estos autores que no escribió sobre o a Miró, a excepción de las dos cartas ya citadas. Sin embargo, compartía con ellos un mismo gusto por la perfección formal, así como una misma pasión por Góngora, por lo que es plausible, a la luz de todo lo visto, que también admirara a Miró, y fuera para él un referente literario. De Góngora, dijo Lorca «que estaba solo como un leproso de llagas de fría luz de plata» ${ }^{123}$.

${ }^{123}$ LORCA. «La imagen», p. 244. 
La descripción no puede ser más mironiana. Parece Góngora descrito como el obispo leproso de Miró: «Don Magín fue descogiéndole los vendajes y apareció el metacarpo, acortejado de racimillos de vesícula» (OC, p. 925). O como uno de los leprosos de Del vivir: "Y sus ojos, hundidos entre llagas, expresaban inmensamente; eran hoscos, mates, secos; pero había momentos en que tornábanse lucientes, húmedos... Tenía esa humedad de que nace la lágrima sin que ésta asome y caiga aliviadora» $(O C$, p. 22). Lorca, además, describe la lepra de Góngora con esa mironiana forma, ya mencionada, de embellecer la fealdad, convirtiendo las llagas, metafóricamente, en «luz de plata». Y es una imagen construida con una cascada de genitivos («de llagas de fría luz de plaza»), recurso tan mironiana como apuntaba Guillén, y haciendo referencia a la luz de la luna.

A menudo se ha estudiado el motivo de la luna en Miró. Diego se asombra de «Cuántas lunas en Gabriel Miró. He anotado en una rápida cosecha más de cuarenta» ${ }^{124}$. Siendo la luna un motivo lorquiano por excelencia $^{125}$, es posible que Lorca lo aprendiera - al menos en parte- de Miró. Especialmente en dos sentidos. (i) El valor sensual de la luna, relacionada siempre con la mujer. Miró ofrece un ejemplo de ello en la violación de una leprosa en Del vivir, que tiene lugar mientras «Del cielo caía la lluvia de la luna» $(O C$, p. 16). Lorca da una escena parecida con una «luna de pergamino» que presencia cómo el viento lascivo quiere violar a Preciosa: «Preciosa tira el pandero / y corre sin detenerse. / El vientohombrón la persigue / con una espada ardiente» ${ }^{126}$. (ii) La luna, como estos dos mismos casos ejemplifican, es testigo de la tragedia, tanto en Miró como en Lorca. Miró, en El abuelo del rey (1915), narra cómo Agustín experimenta la muerte de Carlota recordando, a la luz de la luna, su miseria: «Había entrado la luna llena en el huerto; y abrió la oscuridad de la alberca que parecía un arca de plata colmada de joyas y de vestiduras blancas, purísimas, de todas las mujeres que murieron tristes» (p. 515). En Bodas de sangre (estrenada en 1933, publicada en 1936), el desenlace trágico que idea Lorca se da en el bosque, ante el acecho de una luna personificada que se refleja, como tantas veces en Miró, en el agua de una alberca: «me anega, pura y fría, / el agua de los estanques» ${ }^{127}$.

En el siguiente pasaje de Años y leguas, diferentes motivos, además de la funesta luna, parecen ser antecedentes de Lorca:

${ }^{124}$ DIEGO. «Gabriel Miró», p. 205.

125 Véase, por ejemplo, CORREA, Gustavo. «El simbolismo de la luna en la poesía de Federico García Lorca». Publications of the Modern Language Asociation. 1957, 72, pp. 1060-1084.

${ }^{126}$ GARCÍA LORCA, Federico. Romancero Gitano. Sonetos del Amor Oscuro. Buenos Aires: Losada, 1999, pp. 59-60.

${ }^{127}$ GARCÍA LORCA, Federico. Bodas de sangre. Josephs, Allen; Caballero, Juan (eds.). Madrid: Cátedra, 2001, p. 144. 
Tiene [la cordera] el cuello rajado a dentelladas; y los finos vellones se le acortezan de sangre dura y de babas gordas, como si le hubiese hollado la piel un caracol monstruoso.

Gregorio da un grito de perdición y se abalanza contra el burro. La bestia le aguarda inmóvil y triste; y con los ojos mojados de arrepentimiento ha ido confesándolo todo:

- ¡He sido yo; se lo hice yo anoche! Fue sin querer, amo mío. Entró la luna y nos pusimos a jugar la Paloma y yo. Yo estaba tan contento que retozaba creyéndome un cordero novio. Mis quijadas se hundían en su cuello tierno como una hierba. La Paloma se quejaba y yo venga de morderle y de pasarle mi lengua caliente como una mano. ¡Mis orejas parecían dos ramas de ciruelo en flor! ¡Yo no me acordaba de lo que era, porque yo estaba, amo mío, yo estaba también muy jovencito y guapo de luna! (OC, p. 1108).

El burro (posible antecesor del caballo lorquiano, símbolo de potencias sexuales y viriles ${ }^{128}$ ) ataca a la cordera con una violencia sexual embellecida con un tipo de metáforas hiperbólicas, parecidas a las que usará Lorca. Así las «babas gordas, como si le hubiese hollado la piel un caracol monstruoso» es pre-lorquiano por lo líricamente exagerado de la metáfora, que pone, además, en relación, como Góngora, elementos distantes (babas de un burro con babas de caracol, asimilado a un caballo por su cualidad de hollar la piel). Compárese con un ejemplo de Lorca: «Lloraba como un torito, con la fuerza de mil cigarras cantando a la vez» ${ }^{129}$ (elementos distantes como «torito» y «cigarras»). Pero el pasaje también es pre-lorquiano por el símbolo del caracol, lleno de connotaciones sexuales. Lorca lo usa, por ejemplo, en El público (1930): «Amor de caracol, col, col, col, / que saca los cuernos al sol» ${ }^{130}$. Aquí, Lorca hace de los cuernos una imagen fálica, muy al estilo de Miró en «Mis orejas parecían dos ramas de ciruelo en flor». Por lo que respecta a la hipérbole, compárese en Miró «La mano de Visentot [que] era una cepa que cubría toda la mesita del comedor» $(O C$, p. 1166), con esta imagen de Lorca: «Un gigante. Un gigante, tan gigante, que puedo bordar una rosa en la uña de un niño recién nacido» (Público, p. 134).

El motivo telúrico de la luna y el uso de la hipérbole permite pasar a la tragedia rural de Lorca. Miró pudo servirle de modelo en lo que se refiere al contexto represivo de la ciudad levítica, que, con sus valores, se manifiesta en personajes bestiales. Miró hace que Visentot posea una mano gigantesca como símbolo hiperbólico de una fuerza bestial, con la que deja

128 «El caballo, a su vez, es uno de los símbolos más reiterados en la obra de Lorca, como símbolo de masculinidad, de sexualidad y de fuerza», explica GÓMEZ YEBRA, Antonio A. Estudios sobre el 27. V. Aleixandre, F. García Lorca, J. Guillén, E. Prados (Prosa, teatro, poesía, aspectos biográficos). Málaga: Sarriá, 2000, p. 113.

${ }^{129}$ GARCÍA LORCA, Federico. Yerma. Gil, Ildefonso-Manuel (ed.). Madrid: Cátedra, 2003, p. 49.

${ }^{130}$ Idem, El público. Clemente Millán, María (ed.). Madrid: Cátedra, 1988, p. 150. En adelante, Público más n. ${ }^{\circ}$ de p. entre paréntesis. 
sorda a su mujer. Fuerza bestial, represiva que Lorca representa muy a menudo de manera similar — por cuanto de hipérbole y símbolo tiene-, y que llegó a retratar mejor con el personaje de Bernarda Alba. Miró también pudo darle un antecedente a Lorca en el tema de la neurosis que se deriva de una exagerada represión sexual conservadora: «Gran conocedor del genuino fenómeno religioso, tal vez fue [Miró] el primero en comprender que una neurosis de represión sexual era componente clave de las actitudes mentales de la España retrógrada, y con ello brindó uno de sus grandes temas a Federico García Lorca. Las dos novelas de Oleza tienen por foco la desintegración de una gran Casa de Bernarda Alba. Y ésta, a su vez, es una minúscula Oleza, sólo que regida por el Padre Bellod y no por El obispo leproso» ${ }^{131}$. Esta hipótesis la secunda Altisent, «por la creación [mironiana] de un ámbito levítico y feudal, centrado en una figura tiránica femenina (tradición que va de doña Perfecta a Bernarda Alba)» ${ }^{132}$. $\mathrm{Y}$ es que Bernarda Alba pudo tener su antecedente en la doña Elvira de las novelas de Oleza, por ser ambas celosísimas y autoritarias guardianas de la pureza moral, aterradas del qué dirán. Otro antecedente pudo ser el de la Señora de Los pies y los zapatos de Enriqueta, porque tiene una fuerza mucho mayor y estricta que la de Elvira, y «es el prototipo de la cacique que se empeña en manejar los hilos de todas las vidas sobre las que cree tener un derecho concedido por el Omnipotente, segura de la justicia y el bien de sus decisiones, aunque, en rigor, sus acciones no siembren más que desconsuelo» ${ }^{133}$. En efecto, Bernarda está convencida del derecho absoluto de su poder/fuerza, pese a que ello traiga consigo el suicidio final. En última instancia, la tragedia/drama, tanto en Miró como el Lorca, tiene su origen en la represión sexual que se deriva de una moral conservadora radical y que ambos proyectan en mujeres hiperbolizadas en sus atributos represivos.

Es muy arriesgado entrar a analizar todos estos motivos lorquianos con la rapidez con que se ha hecho. Sería imposible afirmar que Miró sea el antecedente directo/único de Lorca de todos ellos, entre otras cosas porque cualquier estudio especializado de Lorca podría proporcionar una visión mucho más amplia, defendiendo el carácter absolutamente personalísimo y original de estos motivos, o mostrando diferentes orígenes e influencia. Sin embargo, cabe pensar que entre todos ello, y a la luz de la mostrada relación que hubo entre ambos autores, dentro del marco del 27 y de Góngora, Miró fuera uno más, hasta ahora desapercibido.

\footnotetext{
131 MÁRQUEZ VILLANUEVA. Esfinge, p. 27.

132 ALTISENT, Marta. La narrativa breve de Gabriel Miró. Y antología de cuentos. Barcelona: Anthropos, 1988, p. 192.

${ }^{133}$ BARBERO, Teresa. Gabriel Miró. Madrid: Epesa, 1974, pp. 121-122.
} 


\section{CONCLUSIÓN: MiRó Y EL 27 EN EL MARCO NEOMODERNiSTA}

La lectura no narrativa de Gabriel Miró parte de sus años en vida, cuando se le interpretó como estilista sin nada que decir. Se trataba de una visión negativa, compartida por casi todos los críticos de entonces, y hasta por personajes tan relevantes como Ortega. Sólo algún escritor de peso, como Unamuno, admiró y defendió a Miró antes que el 27. Fueron los poetas de esta generación los que más contundentemente se afanaron en rescatar a Miró del peyorativo marbete de estilista, ofreciendo una más moderna lectura de su obra, en paralelo a la de Góngora. Pero su postura seguía sin ofrecer al narrador, limitada en el nuevo marbete de lírico. Se interesaron en los aspectos de Miró más cercanos a la poesía: el lenguaje, la arquitectura lingüística, la metáfora, etc. Y su peculiar revalorización de Miró fue tan fuerte, sobre todo cuando estuvo en manos de profesores de universidad como Salinas y Guillén, que impidió el desarrollo de otro tipo de lectura narrativa de su obra, y condicionó, tal vez más que ningún otro crítico anterior, los estudios mironianos posteriores a la superficialidad de lo lírico-estilístico. Que en la poesía del 27, fruto de esta admiración, hubiera influencia de Miró, y que fuera, a tenor de los rasgos que ellos destacaron, eminentemente poética (en estilo y ciertos temas, como la palabra) reforzaría más aún esta imagen, ya que aquellos autores no sólo la proyectarían en sus escritos ensayísticos, sino a través de su propia práctica literaria.

Por falta de espacio, no se ha entrado a debatir y aclarar el complicado concepto de influencia, pero tampoco se ha querido afirmar que se dé en un sentido estricto en casi ninguno. Es más factible en Guillén, Salinas, Diego e incluso Alberti por existir datos fehacientes en su relación con Miró; el caso de Lorca ha de tratarse con más cuidado, porque sólo hay dos testimonios escritos, en forma de cartas, de que lo conociera y, tal vez, admirara. En todos ellos, así como en Alonso, es posible, no obstante, que Miró, en el contexto de las vanguardias, fuera un guía o modelo genérico, especialmente en lo que atañe a una común actitud ante el hecho literario, como construcción lingüística cuidada. Sería como un «hermano espiritual», o «una bandera de libertad creadora, que no les imponía ningún credo ni ningún "ismo" $\gg{ }^{134}$. Una especie de hermano mayor que, por su moderno modo de entender la literatura, a diferencia de otros mayores, estaba poniendo en práctica principios estéticos que ellos defendían y que bien podían haber aprendido por sí mismos o por fuentes comunes, como Góngora. Téngase en cuenta, por ejemplo, cómo el tema de la palabra, con ser mironiano, aparece en Guillén tal vez no tanto por Miró como por la particular lectura que de él hace en Lenguaje y poesía a parir de

${ }^{134}$ MÁRQUEZ VILLANUEVA. Esfinge, p. 37. 
sus propias ideas. El caso de la metáfora, por su parte, aunque usada muy frecuentemente por Miró, era una aspiración estética de la época, en el marco de las vanguardias y tras los logros del modernismo. Góngora era también un estandarte metafórico para todos, de modo que Miró puede presentarse como un filtro entre aquél y el 27. Más que influencia, pues, podría hablarse de confluencia estética epocal, con el denominador común de Góngora. Se trata aquél de un momento que, asumiendo los logros del modernismo, avanza hacia la vanguardia, de ahí que Baquero hable de «La prosa neomodernista de Gabriel Miró». Cabe decir que los temas y estilemas aquí tratados funcionan en el 27, más que como influencia directa de Miró, como parte de un contexto estético neomodernista, un intertexto de maestros y referentes muy complejo, en el que hay que tener en cuenta, obviamente, aquellos que ya se han reconocido, como, aparte de Góngora, Juan Ramón Jiménez. Pero a la luz de lo que aquí se ha visto no puede negarse que Miró se integra en ese intertexto, convirtiéndose en otro actor más en la formación estética y literaria de este grupo de poetas.

No obstante esta matización, dada la mayor cercanía personal de Salinas y Guillén con Miró, se ha destacado en ellos algunas influencias más claras, en especial en torno al tema de la palabra. En Alonso no se han encontrado huellas concretas; en Diego, sólo unas pocas, y apenas en ejemplos de metáfora, pese a haber sido él el poeta adscrito a una de las vanguardias literarias que ensalzó este tropo. Y en Alberti (pese a los datos de que lo admiró y conoció) y Lorca (con los pocos indicios objetivos de que se dispone en lo que atañe a su relación con Miró) se ha creído más oportuno hablar de cercanías. En cualquier caso, lo que se ha dicho de todos no es más que una primera aproximación, y, sobre todo en lo que atañe a Lorca, sería deseable un estudio de influencias más detallado, acaso completándose con la proyección de Miró en los narradores de aquella generación (Juan Chabás, Benjamín Jarnés, etc.).

Fecha de recepción: 10 de noviembre de 2008

Fecha de aceptación: 26 de mayo de 2009 